
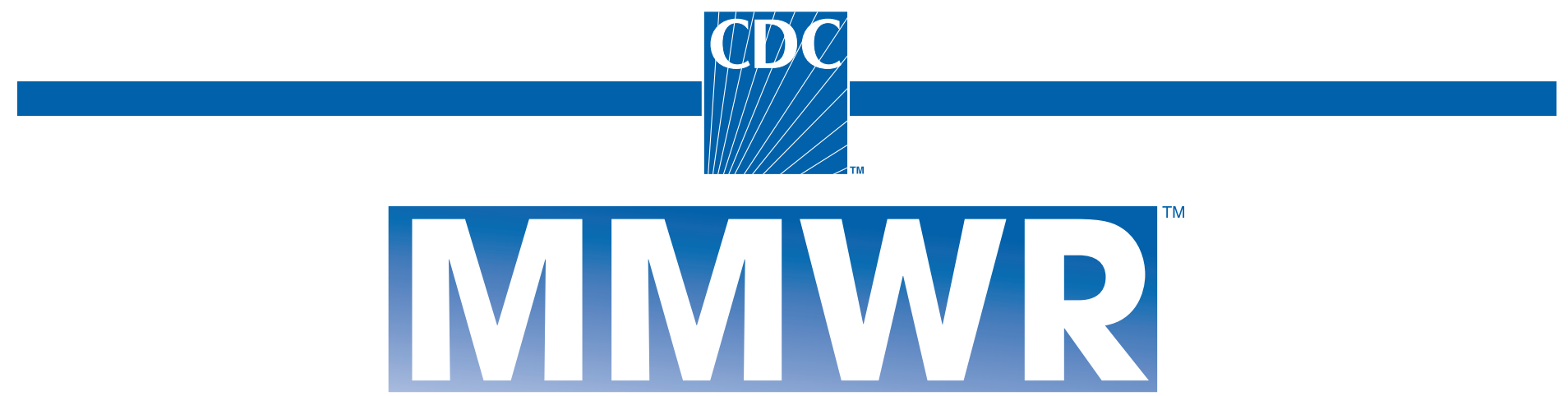

Morbidity and Mortality Weekly Report

Weekly

January 25, 2002 / Vol. 51 / No. 3

\title{
Recent Trends in Mortality Rates for Four Major Cancers, by Sex and Race/Ethnicity - United States, 1990-1998
}

In $1998,53 \%$ of all cancer-related deaths in the United States were associated with four sites: lung/bronchus, colon/ rectum, prostate, and female breast $(1)$. Cancer-related death does not affect racial/ethnic populations similarly. In 1996, the National Cancer Institute (NCI) published cancer incidence and death rates during 1988-1992 in 10 categories of race/ethnicity (2). To examine trends during 1990-1998 in annual death rates for the four major cancers by sex and race/ ethnicity (i.e., blacks, whites, Hispanics, American Indians/ Alaska Natives [AI/ANs], and Asians/Pacific Islanders [APIs]), CDC analyzed data from the National Center for Health Statistics' National Vital Statistics System (3). This report summarizes the results of that analysis, which indicated that, except for lung cancer in women and lung, colorectal, and breast cancer in $\mathrm{AI} / \mathrm{ANs}$, trends in death rates from these cancers have generally declined. But the rates remained high for blacks, have not decreased equally among all populations, and have increased in certain instances. Continuing research and prevention efforts are needed to reach high-risk and underserved populations and to understand the reasons for differences in cancer mortality among racial/ethnic populations.

In each state, attending physicians report and file causes of death on death certificates, which then are consolidated into the National Vital Statistics System. For this analysis, the International Classification of Diseases, Ninth Revision, (ICD9) codes* for cause of death from these cancers and NCI software were used to compute death rates as the number of deaths per 100,000 population, age-adjusted to the 1970 U.S. population by using 5 -year age intervals. Deaths and death rates were presented for 1990-1998 for whites, blacks, Hispanics,

*Codes: lung and bronchus 162.2-162.5, 162.8-162.9; colon and rectum 153, 154.0-154.1, 159.0; prostate 185; breast 174 .
AI/ANs, and APIs. To test for significant trends in death rates during 1990-1998, linear regression was used to estimate the annual percentage change for this period.

Data from 1998 indicated that death rates for lung and bronchus cancer were higher for blacks and whites than for other races/ethnicities (Table 1). Death rates for black men were higher than for white men. Among men, death rates from lung and bronchus cancer decreased $1 \%$ to $2 \%$ per year for each race/ethnicity except AI/ANs. Among AI/ANs, death rates increased $1.7 \%$ per year among men and $2.9 \%$ per year among women. Death rates also increased for white and black women.

For 1998, death rates for colorectal cancer for each race/ ethnicity were approximately $40 \%$ higher among men than women (Table 1). Blacks had the highest death rate for colorectal cancer, followed by whites. Death rates for colorectal cancer decreased $2.2 \%$ per year for white men and $1.8 \%$ per year for white women. Declines in death rates among black men and women were approximately $50 \%$ less than that for whites. Death rates for colorectal cancer increased $4.5 \%$ per year for AI/AN men, although the increase was not significant because of year-to-year variations in rates.
INSIDE
53 Immunization Registry Use and Progress - United States, 2001
56 Emergency Medical System Responses to Suicide- Related Calls - Maine, November 1999-October 2000
59 Notice to Readers 
The $M M W R$ series of publications is published by the Epidemiology Program Office, Centers for Disease Control and Prevention (CDC), U.S. Department of Health and Human Services, Atlanta, GA 30333.

\section{SUGGESTED CITATION}

Centers for Disease Control and Prevention. [Article Title]. MMWR 2002;51:[inclusive page numbers].

\section{Centers for Disease Control and Prevention}

Jeffrey P. Koplan, M.D., M.P.H. Director

David W. Fleming, M.D. Deputy Director for Science and Public Health

Dixie E. Snider, Jr., M.D., M.P.H. Associate Director for Science

Epidemiology Program Office

Stephen B. Thacker, M.D., M.Sc. Director

Office of Scientific and Health Communications

John W. Ward, M.D.

Director

Editor, MMWR Series

David C. Johnson

Acting Managing Editor, MMWR (Weekly)

Jill Crane

C. Kay Smith-Akin, M.Ed.

Writers/Editors, MMWR (Weekly)

Lynda G. Cupell

Beverly J. Holland

Visual Information Specialists

Michele D. Renshaw

Erica R. Shaver

Information Technology Specialists

\section{Division of Public Health Surveillance} and Informatics

Notifiable Disease Morbidity and 122 Cities Mortality Data

Carol M. Knowles

Deborah A. Adams

Felicia J. Connor

Patsy A. Hall

Mechele A. Hester

Pearl C. Sharp
Death rates for prostate cancer were more than twice as high for blacks than for whites (Table 1). Rates were lowest among APIs. Death rates decreased for men of each race/ethnicity except AI/ANs (Table 1, Figure 1). The declines in death rates for whites $(2.8 \%$ per year) and APIs $(3.4 \%$ per year) were approximately twice the decreases for blacks, Hispanics, and $\mathrm{AI} / \mathrm{AN}$ s.

Female breast cancer death rates were highest for blacks, followed by whites, Hispanics, AI/ANs, and APIs (Table 1). During 1990-1998, breast cancer-related death rates decreased for white (2.5\% per year) and Hispanic (1.2\% per year) women and were unchanged for black, AI/AN, and API women (Table 1, Figure 2).

Reported by: $P$ Gargiullo, PhD, PA Wingo, PhD, RJ Coates, $P h D$, TD Thompson, Div of Cancer Prevention and Control, National Center for Chronic Disease Prevention and Health Promotion, CDC.

Editorial Note: The findings in this report indicate that death rates have declined for lung and bronchus, colorectal, prostate, and female breast cancers among most racial/ethnic populations; however, death rates remained high for certain cancers among blacks and are generally increasing among AI/ANs. Trends in cancer death rates might reflect changes in cancer risk behaviors, new screening modalities, and the development and use of new and more effective treatments (1).

Lung and bronchus cancer was the most important cause of cancer mortality in the 1990s, accounting for approximately $28 \%$ of all cancer-related deaths (1). Approximately $90 \%$ of these deaths have been attributed to smoking $(4,5)$. Changes in death rates reflect substantial decreases in smoking during $1965-1985$ among men (51.9\% to $32.6 \%)$ and smaller decreases among women (33.9\% to $27.9 \%)$ (5). Increases in death rates for AI/ANs probably reflect increases in smoking rates. AI/ANs have among the highest smoking rates in the United States (6).

Incidence of colorectal cancer among whites has been decreasing since approximately 1985 and has remained virtually unchanged for blacks, AI/ANs, APIs, and Hispanics. In the 1990s, decreases in death rates might relate to the increased use of chemotherapy and to screening and early detection (7). During 1987-1998, the percentage of persons aged $\geq 50$ years who ever had sigmoidoscopy/proctoscopy increased from $24 \%$ to $38 \%$. During 1992-1998, the percentage of persons in this age group who had had fecal occult blood testing within a 2-year period increased from $30 \%$ to $33 \%$ (7).

Prostate cancer is second to lung cancer as a cause of cancer-related death among men. The gradual decreases in death rates for all the reported races/ethnicities during the study period might reflect aggressive treatment of advanced 
TABLE 1. Number of deaths and death rate* among persons with cancer and annual percentage change from 1990 to 1998 , by type of cancer, sex, and race/ethnicity — United States, 1990-1998

\begin{tabular}{|c|c|c|c|c|c|}
\hline \multirow[b]{2}{*}{ Type of cancer } & \multicolumn{2}{|c|}{ No. of deaths } & \multicolumn{2}{|c|}{ Aqe-adjusted rates } & \multirow{2}{*}{$\begin{array}{c}\text { Annual } \\
\% \text { change } \\
1990-1998\end{array}$} \\
\hline & 1990 & 1998 & 1990 & 1998 & \\
\hline \multicolumn{6}{|l|}{ Lung and bronchus } \\
\hline Men & 91,012 & 91,397 & 75.2 & 65.4 & $-1.8^{\dagger}$ \\
\hline Whites & 79,420 & 79,608 & 73.2 & 64.2 & $-1.7^{\dagger}$ \\
\hline Blacks & 10,621 & 10,280 & 107.0 & 88.8 & $-2.3^{\dagger}$ \\
\hline American Indians/Alaska Natives & 205 & 325 & 37.5 & 45.3 & $1.7^{\dagger}$ \\
\hline Asians/Pacific Islanders & 756 & 1,184 & 34.1 & 33.5 & $-1.2^{\dagger}$ \\
\hline Hispanics§ & 1,813 & 2,245 & 34.7 & 28.6 & $-2.1^{\dagger}$ \\
\hline Women & 50,134 & 63,075 & 31.6 & 34.6 & $1.1^{\dagger}$ \\
\hline Whites & 45,112 & 56,342 & 32.0 & 35.3 & $1.2^{\dagger}$ \\
\hline Blacks & 4,503 & 5,813 & 31.8 & 34.7 & $1.0^{\dagger}$ \\
\hline American Indians/Alaska Natives & 117 & 202 & 16.5 & 22.5 & $2.9^{\dagger}$ \\
\hline Asians/Pacific Islanders & 397 & 718 & 14.5 & 15.4 & 0.9 \\
\hline Hispanics & 780 & 1,104 & 11.2 & 10.6 & -0.2 \\
\hline \multicolumn{6}{|l|}{ Colorectal cancer } \\
\hline Men & 28,481 & 28,023 & 23.4 & 19.6 & $-2.1^{\dagger}$ \\
\hline Whites & 25,233 & 24,381 & 23.1 & 19.2 & $-2.2^{\dagger}$ \\
\hline Blacks & 2,879 & 3,074 & 29.2 & 26.2 & $-0.9^{\dagger}$ \\
\hline American Indians/Alaska Natives & 52 & 94 & 9.6 & 12.7 & 4.5 \\
\hline Asians/Pacific Islanders & 314 & 474 & 13.9 & 12.9 & $-1.5^{\dagger}$ \\
\hline Hispanics & 744 & 1,051 & 14.2 & 13.0 & -0.5 \\
\hline Women & 28,673 & 28,950 & 15.6 & 13.7 & $-1.7^{\dagger}$ \\
\hline Whites & 25,213 & 24,936 & 15.2 & 13.2 & $-1.8^{\dagger}$ \\
\hline Blacks & 3,158 & 3,506 & 20.7 & 19.4 & $-0.8^{\dagger}$ \\
\hline American Indians/Alaska Natives & 61 & 93 & 8.3 & 9.2 & 1.2 \\
\hline Asians/Pacific Islanders & 238 & 415 & 8.7 & 8.7 & -0.5 \\
\hline Hispanics & 653 & 842 & 9.1 & 7.7 & $-1.9^{\dagger}$ \\
\hline Prostate & 32,376 & 32,203 & 26.4 & 21.5 & $-2.6^{\dagger}$ \\
\hline Whites & 26,915 & 26,416 & 24.3 & 19.6 & $-2.8^{\dagger}$ \\
\hline Blacks & 5,181 & 5,436 & 54.8 & 48.7 & $-1.5^{\dagger}$ \\
\hline American Indians/Alaska Natives & 59 & 80 & 12.4 & 11.3 & -1.5 \\
\hline Asians/Pacific Islanders & 220 & 271 & 11.1 & 8.0 & $-3.4^{\dagger}$ \\
\hline Hispanics & 724 & 1,089 & 15.6 & 14.7 & -1.7 \\
\hline Breast (Women) & 43,389 & 41,736 & 27.4 & 22.7 & $-2.3^{\dagger}$ \\
\hline Whites & 38,284 & 35,758 & 27.3 & 22.2 & $-2.5^{\dagger}$ \\
\hline Blacks & 4,659 & 5,281 & 31.6 & 29.6 & -0.5 \\
\hline American Indians/Alaska Natives & 89 & 120 & 11.5 & 12.0 & 1.4 \\
\hline Asians/Pacific Islanders & 354 & 577 & 11.2 & 11.2 & -1.0 \\
\hline Hispanics & 1,244 & 1,591 & 16.4 & 14.2 & $-1.2^{\dagger}$ \\
\hline
\end{tabular}

* Per 100,000 population; rates age-adjusted to the 1970 U.S. standard million population.

Significantly different from zero $(p \leq 0.05)$.

$\S$ Deaths among Hispanics are not mutually exclusive of deaths among the four race/ethnicity categories. Deaths and death rates for Hispanics do not include data from Connecticut, Louisiana, New Hampshire, and Oklahoma because data on Hispanic origin were not available for certain years.

cancer and use of serum prostate-specific antigen (PSA) testing $(1)$. However, the effectiveness of PSA screening and earlystage treatment in reducing mortality is unknown.

Breast cancer accounts for the second largest proportion of cancer-related deaths among women (1). The recent increase in the incidence of breast cancer probably reflects greater use of screening and early detection because the increase has occurred mostly among women diagnosed with early-stage disease (1). By 1997, the percentage of women aged $\geq 40$ years who reported having had a mammogram during the preceding 2 years was $72.9 \%$ for blacks, $72.5 \%$ for APIs,
$71.4 \%$ for whites, $67 \%$ for Hispanics, and $59.9 \%$ for AI/ ANs (8).

The findings in this report are subject to at least two limitations. First, the reporting of race/ethnicity to the U.S. Bureau of the Census and on death certificates usually is reliable for blacks and whites (9); however, underreporting for other races/ ethnicities can understate death rates from $2 \%$ among Hispanics to $21 \%$ among AI/ANs. Second, because this study was a description of national trends and not an evaluation of cancer intervention studies, the findings should be interpreted with caution. 
FIGURE 1. Rate* of prostate cancer deaths, by race/ethnicity - United States, 1990-1998

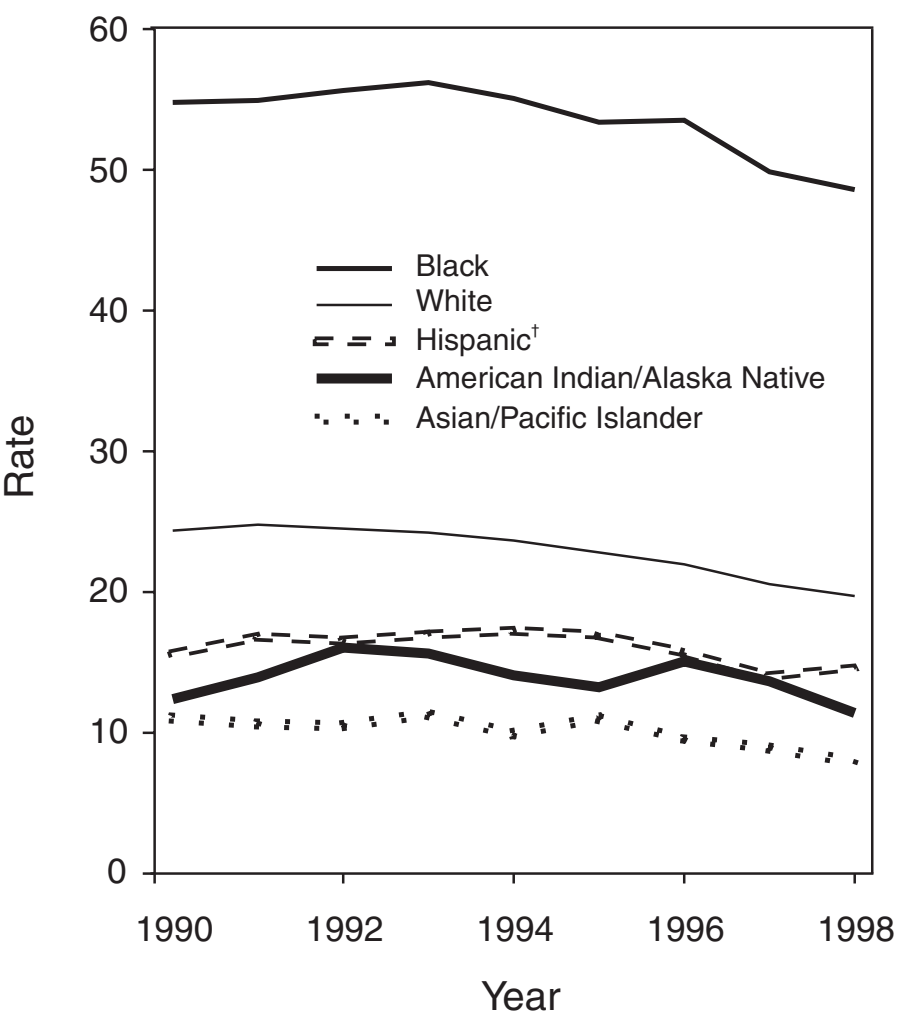

* Per 100,000 population; rates age-adjusted to the 1970 U.S. standard million population.

${ }^{\dagger}$ Deaths among Hispanics are not mutually exclusive of deaths among the four race/ethnicity categories. Death rates for Hispanics do not include data from Connecticut, Louisiana, New Hampshire, and Oklahoma because data on Hispanic origin were not available for certain years.

One of the goals of the national health objectives for 2010 is to eliminate health disparities among racial/ethnic populations. CDC supports several initiatives that address the four major cancers: national tobacco-control efforts; Screen for Life, a multimedia campaign promoting prevention and early detection of colorectal cancer; and Racial and Ethnic Approaches to Community Health (REACH 2010). CDC also funds research on the high death rates from prostate cancer among blacks and the National Breast and Cervical Cancer Early Detection Program, which provides screening to underserved women. Additional information about CDC's cancer prevention and control programs is available at http:// www.cdc.gov/tobacco; http://www.cdc.gov/cancer; and http:// www.cdc.gov/cancer/minorityawareness.htm.

Differences in cancer death rates result from a combination of factors such as behaviors (e.g. smoking and nutrition); access to preventive, diagnostic, therapeutic, and screening services; and aggressiveness of treatment. If these factors were modified, more than half of the cancer deaths could be
FIGURE 2. Rate* of female breast cancer deaths, by race/ ethnicity - United States, 1990-1998

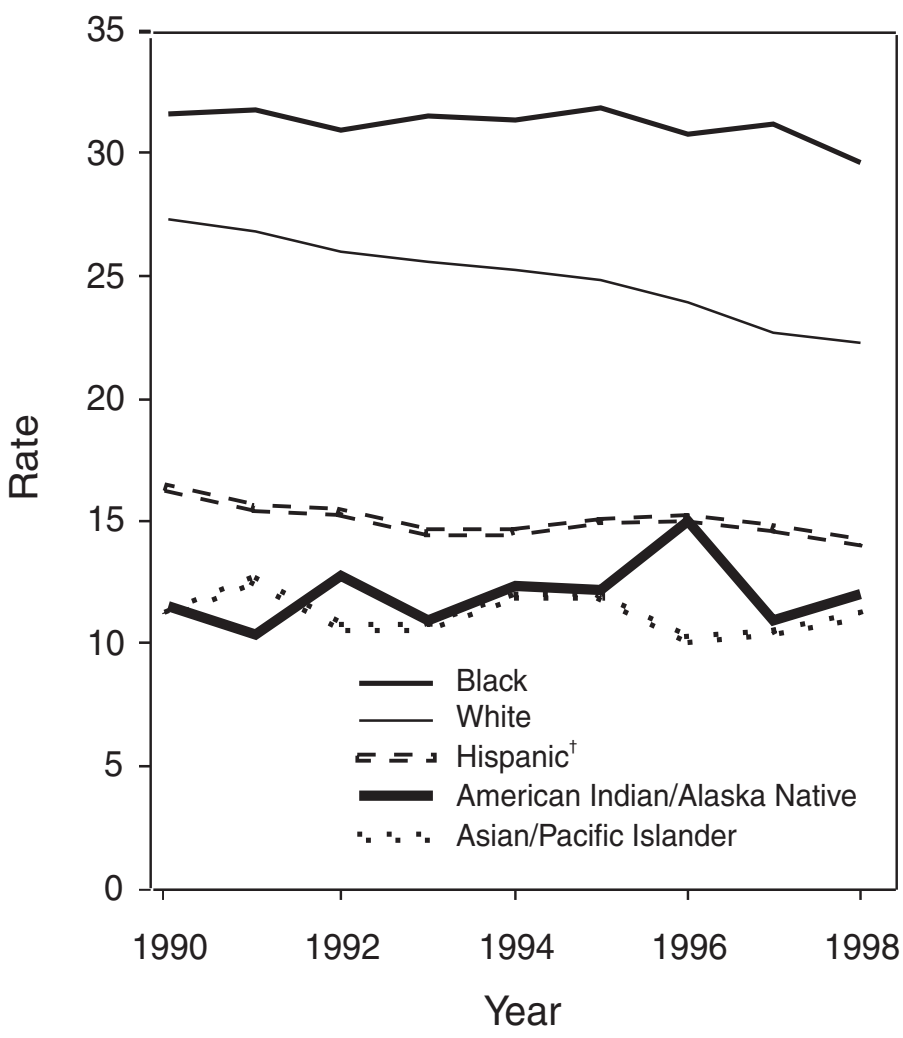

${ }^{*}$ Per 100,000 population; rates age-adjusted to the 1970 U.S. standard million population.

${ }^{\dagger}$ Deaths among Hispanics are not mutually exclusive of deaths among the four race/ethnicity categories. Death rates for Hispanics do not include data from Connecticut, Louisiana, New Hampshire, and Oklahoma because data on Hispanic origin were not available for certain years.

prevented and most racial/ethnic disparities in cancer death rates could be eliminated.

\section{References}

1. Howe HL, Wingo PA, Thun MJ, et al. Annual report to the nation on the status of cancer (1973 through 1998), featuring cancers with recent increasing trends. J Natl Cancer Inst 2001;93:824-42.

2. Miller BA, Kolonel LN, Bernstein L, et al. Racial/ethnic patterns of cancer in the United States 1988-1992. Bethesda, Maryland: National Cancer Institute; 1996. National Institutes of Health publication no. 96-4104.

3. Murphy SL. Deaths: final data for 1998. National Vital Statistics Reports; vol. 48, no. 11. Hyattsville, Maryland: National Center for Health Statistics, July 24, 2000.

4. Harras A, Edwards BK, Blot WJ, Ries LAG, eds. Cancer rates and risks, 4th ed. Bethesda, Maryland: National Cancer Institute, 1996; National Institutes of Health publication no. 96-691.

5. Wingo PA, Ries LAG, Giovino GA, et al. Annual report to the nation on the status of cancer, 1973-1996, with a special section on lung cancer and tobacco smoking. J Natl Cancer Inst 1999;91:675-90.

6. CDC. Cigarette smoking among adults-United States, 1998. MMWR 2000;49:881-4.

7. Ries LAG, Wingo PA, Miller DS, et al. The annual report to the nation on the status of cancer, 1973-1997, with a special section on colorectal cancer. Cancer 2000;88:2398-424. 
8. Blackman DK, Bennett EM, Miller DS. Trends in self-reported use of mammograms (1989-1997) and Papanicolaou tests (1991-1997) Behavioral Risk Factor Surveillance System. MMWR 1999;48(No. SS-6).

9. Rosenberg HM, Maurer JD, Sorlie PD, et al. Quality of death rates by race and Hispanic origin: a summary of current research, 1999. Hyattsville, Maryland: US Department of Health and Human Services, CDC, National Center for Health Statistics, 1999; Vital and Health Statistics, Series 2, No. 128.

\section{Immunization Registry Use and Progress - United States, 2001}

Immunization registries are confidential, population-based, computerized information systems that collect vaccination data about all children within a geographic area (1). Registries are key tools used to increase and sustain high vaccination coverage by providing complete and accurate information on which to base vaccination decisions. Registries consolidate vaccination records of children from multiple healthcare providers, identify children who are due or late for vaccinations, generate reminder and recall notices to ensure that children are appropriately vaccinated, and identify provider sites and geographic areas with low vaccination coverage. One of the national health objectives for 2010 is to increase to $95 \%$ the proportion of children aged $<6$ years who participate in fully operational population-based immunization registries (objective 14-26) (2). CDC analyzed data from 50 states and the District of Columbia (DC) from the calendar year 2000 Immunization Registry Annual Report (CY 2000 IRAR) to assess current registry activity. This report summarizes the results of those analyses, which indicate that 32 $(63 \%)$ of the 51 grantees are operating population-based immunization registries (Figure 1). These 32 projects represent $49 \%$ of the U.S. population aged $<6$ years (3).

FIGURE 1. Percentage of children with $\geq 2$ immunizations listed in a population-based registry - United States, 2000

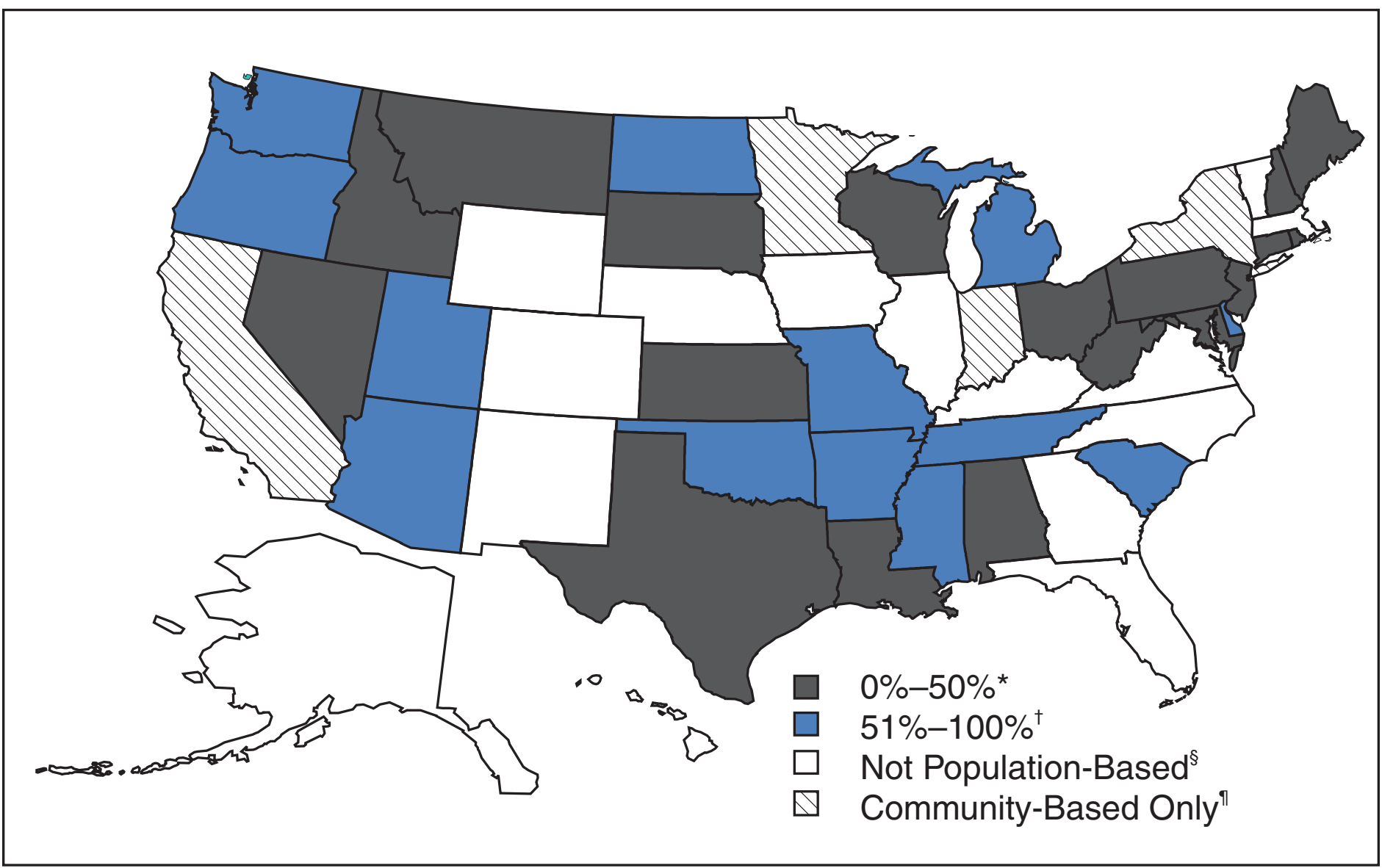

\footnotetext{
* Eighteen states.

$\dagger$ Thirteen states and the District of Columbia.

$\S$ Fifteen states.

"Four states.
} 
The CY 2000 IRAR was a self-administered questionnaire distributed to immunization program managers as part of the yearly reporting requirement for Public Health Service Act $\$ 317 \mathrm{~b}$ grantees. Responses were received from all 50 states and DC. A total of $32(63 \%)$ of the 51 grantees reported operating population-based registries that targeted their entire catchment areas. Of the remaining 19 (37\%) grantees, four $(21 \%)$ reported operating population-based registries in regions or counties as demonstration or pilot projects, and 15 (79\%) were planning or developing population-based registries. The CY 2000 IRAR requested information about the percentage of children and vaccination providers in the registry's catchment area who participated and progress in implementing the 13 functional standards for immunization registry operation (3).

Data from the 32 grantees operating population-based registries indicated that approximately $49 \%$ of the estimated 11.4 million children aged $<6$ years, based on the U.S. Census, in these catchment areas had $\geq 2$ vaccinations recorded in the registry. The 32 grantees also reported that an average of 56\% of public vaccination provider sites and $41 \%$ of private provider sites in their catchment areas participated in the registry during the 6 months preceding completion of the CY 2000 IRAR. All 51 grantees were working to meet key elements of the 13 functional standards established for immunization registries (Table 1). Although no registry has met all key elements of all standards, 14 of the 51 grantees have met all key elements of $\geq 11$ of the standards (3).

Reported by: T Boyd, MS, and RW Linkins, PhD, Data Management Div, National Immunization Program, CDC.
Editorial Note: In 2000, the Institute of Medicine noted, "with the increasing importance of population-based approaches to health system planning and evaluation, immunization registries offer one of the most useful instruments for assessing population-specific effectiveness of health and medical care programs" (4). Projects use their registries for program decision support as exemplified by San Antonio's use of registry data to examine the implementation of new vaccines through the Vaccines for Children (VFC) entitlement program. San Antonio's data demonstrated that, although non-VFC providers began using heptavalent pneumococcal conjugate vaccine (PCV7) soon after licensure, delay in VFC reimbursement might have caused slower PCV7 uptake among VFC-eligible children (5). Other projects have used their registry data to measure reminder/recall system effectiveness (G), identify sources of delayed immunizations (7), and track the implementation of immunization schedule changes (8).

Oregon registry data were used to assess the impact on hepatitis B (HepB) vaccine administration after issuance of the Joint Statement of the American Academy of Pediatrics (AAP) and the U.S. Public Health Service (USPHS) (9) about using thimerosal as a vaccine preservative. Their joint statement recommended reducing infant exposure to thimerosal; specific recommendations were made to postpone the first HepB vaccine dose until age 2-6 months for infants born to hepatitis B surface antigen-negative mothers. Oregon's registry data (which include $88 \%$ of the state's population of children aged $<6$ years) indicated that the average proportion of children participating in the registry per week who were administered

TABLE 1. Number and percentage of the 32 population-based immunization registries that implemented key elements of the 13 functional standards - United States, December 2000

\begin{tabular}{|c|c|c|c|c|}
\hline \multirow[b]{2}{*}{ Functional standard } & \multicolumn{2}{|c|}{$\begin{array}{l}\text { Registries meeting } \\
\text { all key elements }\end{array}$} & \multicolumn{2}{|c|}{$\begin{array}{l}\text { Registries meeting } \\
\geq 1 \text { key elements }\end{array}$} \\
\hline & No. & $(\%)$ & No. & $(\%)$ \\
\hline Electronically store data regarding all National Vaccine Advisory Committee-approved core data elements & 15 & $(46.9)$ & 32 & $(100.0)$ \\
\hline Establish a registry record within 6 weeks of birth for each child born in the catchment area & 27 & $(84.4)$ & 27 & $(84.4)$ \\
\hline Enable access to vaccine information from the registry at the time of encounter & 32 & $(100.0)$ & 32 & $(100.0)$ \\
\hline Receive and process vaccine information within 1 month of vaccine administration & 31 & ( 96.9$)$ & 31 & $(96.9)$ \\
\hline Protect the confidentiality of medical information & 23 & ( 71.9$)$ & 27 & $(84.4)$ \\
\hline Recover lost data (i.e., disaster recovery) & 16 & $(50.0)$ & 32 & (100.0) \\
\hline Ensure the security of medical information & 24 & ( 75.0) & 32 & $(100.0)$ \\
\hline Exchange vaccination records by using Health Level Seven standards* & 2 & $(6.3)$ & 7 & (21.9) \\
\hline $\begin{array}{l}\text { Automatically determine the immunization(s) needed when a person is seen by the health-care provider } \\
\text { for a scheduled vaccination }\end{array}$ & 29 & (90.1) & 29 & (90.1) \\
\hline $\begin{array}{l}\text { Automatically identify persons due or late for vaccinations to enable the production of reminder } \\
\text { and recall notifications }\end{array}$ & 27 & ( 84.4) & 29 & $(90.1)$ \\
\hline Automatically produce vaccination coverage reports by providers, age groups, and geographic areas & 26 & ( 81.3$)$ & 28 & $(87.5)$ \\
\hline Produce authorized immunization records & 28 & ( 87.5) & 28 & ( 87.5) \\
\hline $\begin{array}{l}\text { Consolidate all vaccination records from multiple providers, using deduplication and edit-checking } \\
\text { procedures to optimize accuracy and completeness }\end{array}$ & 15 & $(46.9)$ & 32 & $(100.0)$ \\
\hline
\end{tabular}

* Source: Health Level Seven, Inc. Health level seven. Ann Arbor, Michigan: Health Level Seven, Inc., 2001. Available at http://www.hl7.org. Accessed January 16, 2002. 
HepB vaccine $\leq 5$ days after birth decreased $93 \%$ during the 6 weeks after the report's release (Figure 2). On the basis of these data, Oregon officials contacted health plans, healthcare providers, and local health departments to ensure that the report's recommendations were being followed (i.e., that the first dose of HepB be delayed only for infants born to hepatitis $B$ surface antigen-negative mothers and that providers return to previous infant $\mathrm{HepB}$ vaccination practices after a thimerosal-free alternative became available). Continued monitoring of registry data indicated that, despite the availability of thimerosal-free vaccine in August 1999, by the end of 2000 , administration rates had reached only $88 \%$ of prereport levels for HepB vaccination (8). These data assist education efforts for providers who have not reinstated HepB vaccine recommendations.

CDC recently identified for grantees eight core program attributes in the Immunizations Program Operations Manual released in 2001: population assessment, surveillance, consumer information, service delivery, provider quality assurance, vaccine management, registry development, and program management (10). CY 2000 IRAR data indicate that certain grantees might have the capacity to use registry data to support these program attributes. For example, 42 grantees use registry data to determine vaccine coverage among different segments of the population, and 32 grantees track VFC participant eligibility by using their registries. CDC is collecting data to monitor projects' use of registries and registry data to support each of these program attributes beginning with the CY 2001 IRAR.

The findings in this report are subject to at least three limitations. First, because the annual report relied on self-reported information, bias in reporting could have occurred. However, on-site verification through record reviews and observation of registry operations during the 20 site visits performed in 2000 indicated that $98.3 \%$ of the answers provided by those sites in response to the previous year's annual report were accurate. Second, because only information from these 51 immunization grantees was included in the analyses, any immunization registry development performed by other entities (e.g., city immunization grantees, hospitals, local health departments, and managed care plans) would not be included in these findings. This could result in an underestimation of the degree of registry development in the United States. Finally, the CY 2000 IRAR did not collect information about the completeness or accuracy of immunization data recorded in a registry. Tools are under development at CDC to assist with registry data quality assessment.

Immunization registries continue to develop to improve vaccination coverage and reach the 2010 national health objective of $95 \%$ participation for children aged $<6$ years. Additional information about immunization registries is available from CDC at http://www.cdc.gov/nip/registry; by telephone at 800-799-7062; or by e-mail at siisclear@cdc.gov.

FIGURE 2. Number of children who received first dose of Hepatitis B vaccine $\leq 5$ days after birth - United States, $1999-2000$

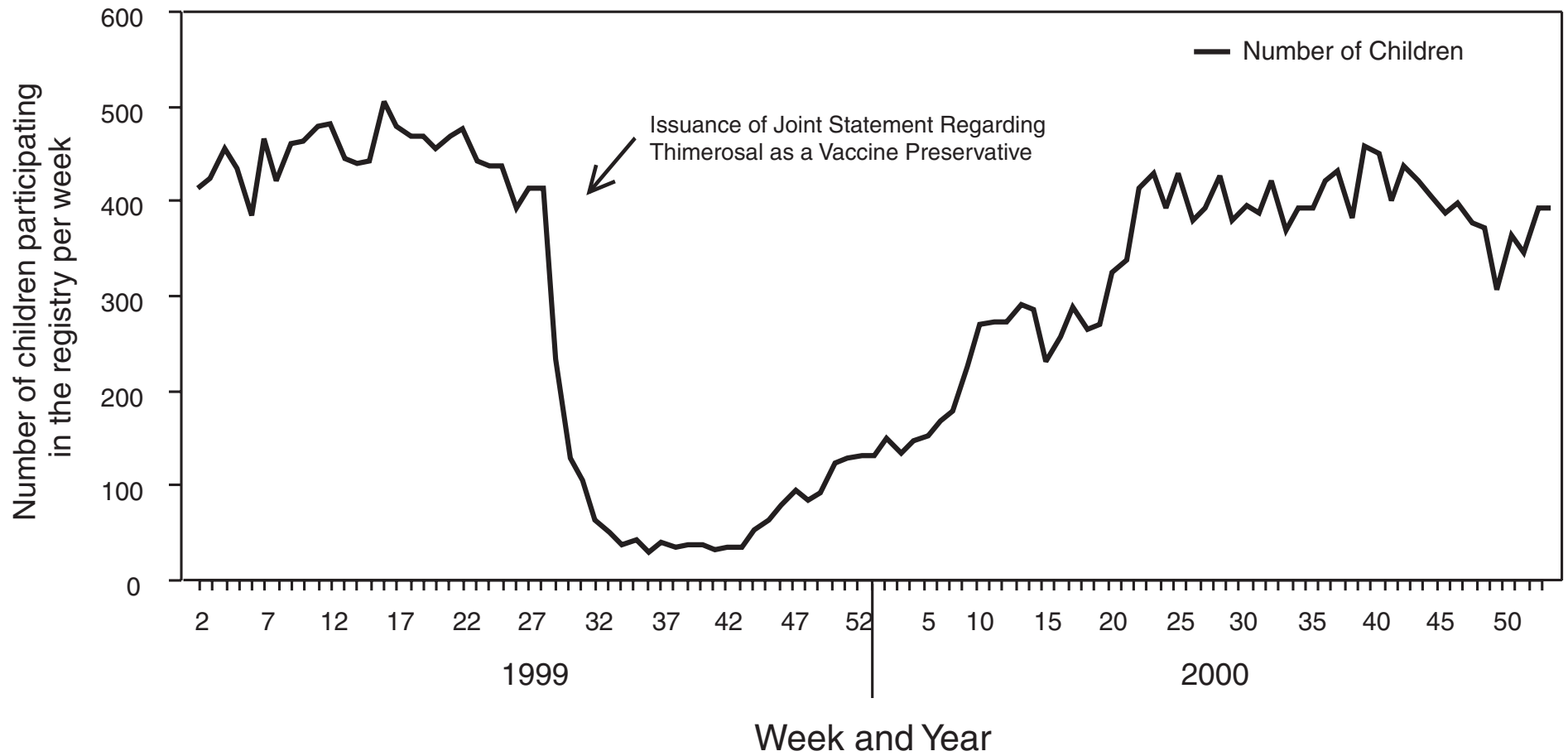




\section{References}

1. National Vaccine Advisory Committee (NVAC). Development of community and state-based immunization registries; approved January 12, 1999. Atlanta, GA: US Department of Health and Human Services, CDC, 1999. Available at http://www.cdc.gov/nip/registry/nvac.htm. Accessed January 16, 2002.

2. US Department of Health and Human Services. Immunizations and infectious diseases. In: Healthy people 2010 (conference ed, vol 1). Washington, DC: US Department of Health and Human Services, 2000:14-41-2. Available at http://www.health.gov/healthypeople. Accessed January 16, 2002.

3. Linkins, R. Current status of registry development. Presented at the 2001 Registry Conference, Little Rock, Arkansas, July 9-11, 2001. Available at http://www.cdc.gov/nip/registry/irc2001 plen.htm. Accessed January 16, 2002.

4. Institute of Medicine. Calling the shots: immunization finance policies and practice. Washington, DC: National Academy Press, 2000. Available at http://www.nap.edu/catalog/9836.html. Accessed January 16, 2002.

5. Poydence, K. Utilization of a metropolitan immunization registry to examine implementation of heptavalent pneumococcal conjugate vaccine. Presented at the 2001 Registry Conference, Little Rock, Arkansas, July 9-11, 2001. Available at http://www.cdc.gov/nip/registry/ irc2001e.htm. Accessed January 16, 2002.

6 . Romey, K. Working with private sector to implement a registry reminder recall system. Presented at the 2001 Registry Conference, Little Rock, Arkansas, July 9-11, 2001.

7. Canavan, B. Using registry data to identify delayed immunization (late starts) for children covered by Medicaid. Presented at the 2001 Registry Conference, Little Rock, Arkansas, July 9-11, 2001.

8. Canavan, B. Using registry data to assess the impact of changes in the vaccine schedule. Presented at the 2001 Registry Conference, Little Rock, Arkansas, July 9-11, 2002. Available at http://www.cdc.gov/ nip/registry/irc2001e.htm. Accessed January 16, 2002.

9. American Academy of Pediatrics. Joint statement of the American Academy of Pediatrics (AAP) and the United States Public Health Service (USPHS) (RE9937). Elk Grove Village, IL: American Academy of Pediatrics, 1999:568-9. Available at http://www.aap.org/policy/ re9937.html. Accessed January 16, 2002.

10. National Immunization Program. Immunization program operations manual. Atlanta, GA: US Department of Health and Human Services, CDC, National Immunization Program, 2001.

\section{Emergency Medical System Responses to Suicide-Related Calls - Maine, November 1999-October 2000}

Suicidal acts are morbid and potentially lethal events that are risks for subsequent completed suicide and possibly other health problems (e.g., substance abuse and depression) $(1,2)$. Suicidal behavior also can have negative consequences on family members, friends, and caregivers (3). In 1996, the cost of health care and lost wages for suicide attempts in Maine was approximately $\$ 115$ million (4). In 1999, a total of 1,079 persons were hospitalized in Maine for self-injurious behavior. Although Maine has no injury-related surveillance systems, the Maine Bureau of Health $(\mathrm{MBOH})$ assessed the use of Emergency Medical Service (EMS) response data to estimate incidence of EMS responses to suicide-related calls in Maine and to summarize the distribution of these responses by patient and event characteristics. This report describes EMS suicide-related responses during November 1999-October 2000 and indicates that EMS data would be a useful component of an integrated statewide suicidal behavior surveillance system.

Maine EMS responders complete a run report form (RRF) for each emergency assistance call. RRF contains a check box titled "concern suicide," which is selected "for patients who have, relevant to this call/run, expressed or displayed any suicidal tendencies or attempts." For any RRF on which "concern suicide" is selected, personal identifiers are removed and the form is sent to the MBOH Injury Prevention Program (MIPP). RRF has defined fields for sex, age, date of birth, incident date, incident location, incident site*, town of residence, insurance payor, and EMS service number. EMS responders can provide additional information in a free text field, from which MIPP extracts data on method of attempt or threat and circumstances surrounding the event.

Inclusion criteria for this analysis were 1) "concern suicide" box checked on the RRF, 2) confirmed Maine residency, 3) aged $>10$ years ${ }^{\dagger}$, and 4) presence of a unique RRF number. If RRFs were duplicated, only one was counted as a case. Of the 2,152 RRFs received during November 1999-October 2000 , a total of 2,036 (95\%) were eligible for inclusion in the analysis, of which 967 (47.5\%) were made for the intra- or interinstitutional transportation of suicidal residents from nursing homes, psychiatric, correctional, or medical facilities ${ }^{\S}$. Data were evaluated separately for all responses and for the 1,069 noninstitutional (NI) responses. All age-adjusted rates were standardized to the 2000 U.S. standard population and included both completed suicides and nonlethal attempts.

For all calls, age-adjusted EMS response rates to "concern suicide" in Maine were 179.2 per 100,000 females and 142.3 per 100,000 for males. For females, age-specific rates were highest among those aged 15-19 years (384.8); for males, rates were highest for those aged 20-24 year (258.1). Because geographic and event data are limited for the institutionalized subgroup, the remainder of the descriptive analysis was limited to the NI cases.

\footnotetext{
*Location is town and state of the incident; site is the type of location (e.g., home, office, school, or highway).

$\dagger$ Age cutoff was set at age 10 years because only three RRFs were submitted for children aged $<10$ years, and suicidal behavior in this age group is sufficiently different than the 10-14 year age group to make comparing them problematic. $\$$ The current data entry system does not allow for distinctions between persons being transported from nursing homes and residential facilities versus from correctional facilities.
} 
For the 1,069 NI cases, age-adjusted EMS response rates were 92.5 and 76.5 among females and males, respectively. Female rates of suicide-related EMS calls were highest among those aged 15-19 years (206.2), but were generally high among females aged 20-44 years (range: 138.8-160.2). Male rates of suicide-related EMS calls were highest among those aged 20-24 years (170.3) and high among those aged 15-19 and 25-34 years (range: 96.0-110.4). Age-specific rates were statistically similar for females aged $20-34$ years and $>55$ years and for males aged 25-54 years. All other age-specific rate differences were statistically significant $(\mathrm{p}<0.05)$. In comparison, suicide completion rates (derived from medical examiner data) were uniform across all female age groups (range: $0-10.7$ ) and were highest among males aged $\geq 45$ years (range: 25.0-34.8) (Figure 1).

Among the 1,069 NI responses, $761(72.0 \%)$ were to the residence of the attempter. EMS calls were most frequent in the summer $(27.1 \%)$ and least frequent in the winter and spring $(23.5 \%$ and $23.3 \%$, respectively).

Among the 963 (90.1\%) NI cases for which method was documented, overdose (29.9\%), "suicidal ideation only" (27.0\%), and laceration (17.7\%) were the most commonly documented methods. Attempts with firearms comprised $3.7 \%$.

FIGURE 1. Rate* of suicide deaths and emergency medical service response to noninstitutionalized residents, by sex and age group - Maine, November 1999-October 2000

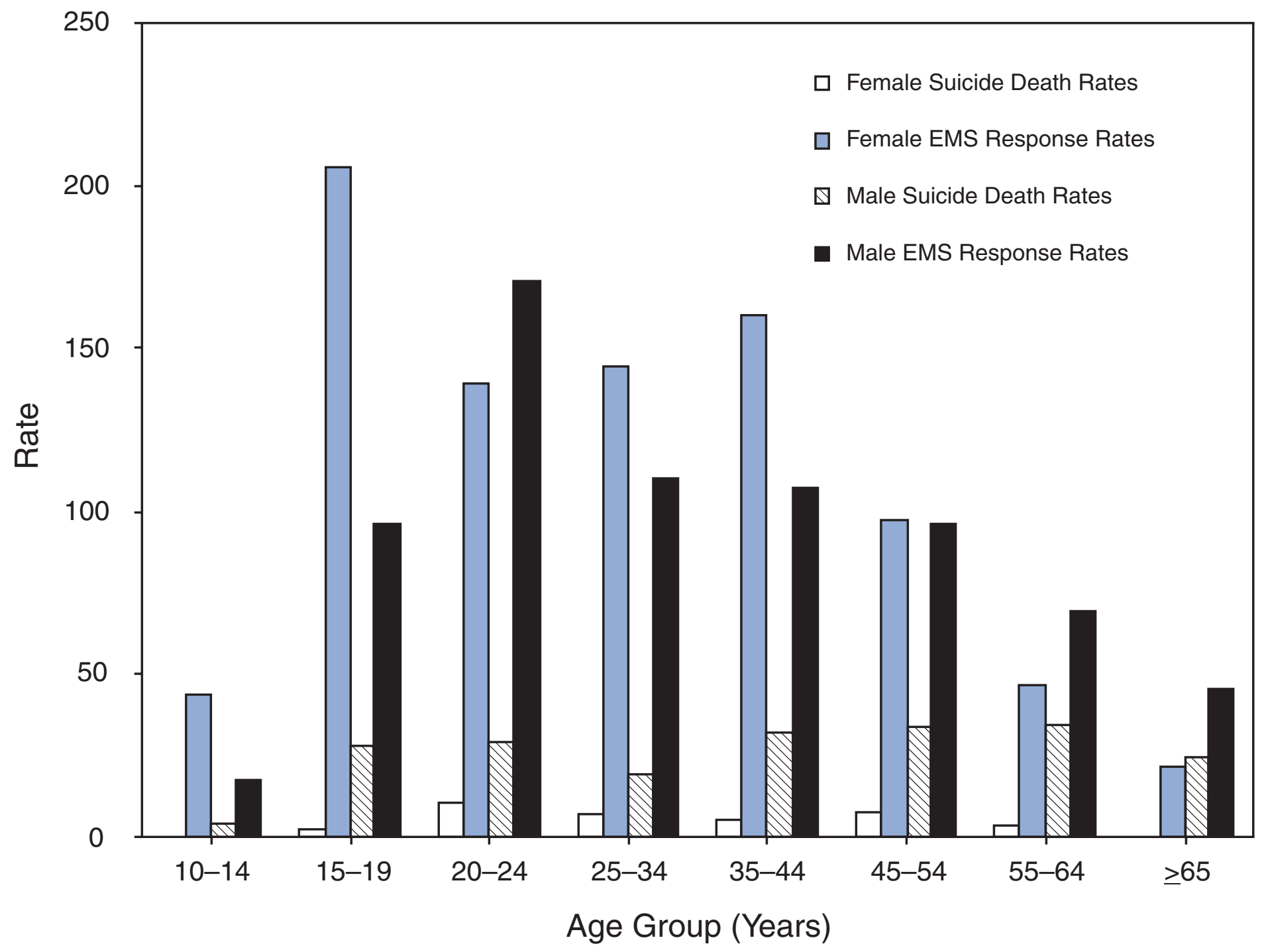

${ }^{*}$ Per 100,000 population 
The case-fatality ratio for EMS calls was 3.8\% (1.3\% for females and $6.9 \%$ for males). Case-fatality ratios were highest among males aged $\geq 65$ years $(15.2 \%)$. Method employed also was related to fatality ratios, even in the minority of completions' receiving EMS response. Of the 36 EMS responses to firearm-related suicidal behavior, 21 (58.3\%) were lethal by the time of RRF completion. Compared with drug overdoses (1.0\% lethal), attempts by firearm and hanging receiving EMS response were 58 and 60 times more lethal, respectively.

Of the 1,069 events, circumstance was reported for 636 $(59.5 \%)$; a total of 695 circumstances were reported. The most commonly reported circumstances were drug/substance abuse at the time of the incident (220 [31.7\%] of all reported circumstances), patient-reported psychiatric illness (200 [28.8\%]), domestic discord or violence (117 [16.8\%]), and medical illness/pain (49 [7.1\%]).

Reported by: N Sonnenfeld, Div of Community Health, Maine Bureau of Health; D Bailey, C DiCara, Injury Prevention Program; J Bradshaw, Maine Emergency Medical Svc. A Crosby, MD, Div of Violence Prevention, National Center for Injury Prevention and Control; $K$ Askland, MD, EIS Officer, CDC.

Editorial Note: Among all states, Maine ranks 14th in rate of suicide deaths (13.4 per 100,000 population); this rate is $25 \%$ higher than the national rate (5). Despite the magnitude of the problem, no surveillance system exists in Maine to monitor suicidal behavior. The findings in this report indicate that EMS NI responses to suicide-related calls in Maine identified characteristics similar to those in community- and population-based studies of nonlethal suicidal behaviors $(6-8)$ and might be an important component of a suicide surveillance system. Virtually all (99\%) EMS response data in Maine from state-, municipal-, volunteer-, and fire-department-based and private services are compiled in a centralized database. In addition, Maine is developing an electronic reporting form and a mobile data input system for use across all 141 EMS services.

The findings in this report are similar to other populationand community-based studies of the distribution of injuries associated with nonfatal suicidal behavior. Findings were similar for age, sex, location, method, and circumstances of suicide-related injuries. Other findings, such as seasonality of the suicidal act and a description of the institutionalized population, might be important for prevention efforts and require further analysis.

9Medical examiner data for November 1999-October 2000 indicated 102 suicides completed by firearm. Therefore, $66(65 \%)$ of firearm-related suicides were completed without an EMS response.
Although this approach demonstrates the value of existing EMS response data for injury surveillance, the findings are subject to several limitations. First, no systematic mechanism exists to ensure that only one RRF is filed for each event or for systematically identifying repeat attempters. Second, the dataset contains only those events for which an RRF is completed. Many persons who contemplate or attempt suicide will not seek assistance and no surveillance instrument, except possibly population-based surveys, will detect these events (1). Despite the lack of prevalence data, demographic and event characteristic profiles parallel those previously documented (1,6-9). Moreover, incidence estimates (i.e., estimates of the total societal burden of attempts) may be most valuable in determining health services needs. Third, because unique record linkages with other health service data systems cannot currently be made, the sensitivity of EMS data, even to those who will eventually visit the emergency department or be admitted to the hospital, is unknown. Finally, this analysis includes data for only 12 months; as a result, the sample size is relatively small, which precludes description of temporal trends over several years. However, analysis at the early stage of development provides opportunities for improving the data collection system and preparing for its use in public health surveillance.

Prevention of suicidal behaviors and attempts might preclude more life-threatening health problems (1). EMS data provide information about suicidal acts and might be useful in early prevention efforts. In addition, EMS data provide event detail unavailable in other health information systems. Data about the circumstances surrounding violent injuries are critical to understand attempt risk and to develop ageand sex-specific prevention strategies. Although refinements are needed, EMS data, together with medical examiner, hospital discharge, and emergency department data, would be a useful component of an integrated statewide suicidal behavior surveillance system (10).

\section{References}

1. Diekstra RFW. Suicide and attempted suicide: an international perspective. Acta Psychiatrica Scandinavica 1989;80:1-24.

2. Moscicki EK. Identification of suicide risk factors using epidemiologic studies. The Psychiatric Clinics of North America 1997;20:499-517.

3. United Nations/World Health Organization. Prevention of suicide: guidelines for the formulation and implementation of national strategies. Geneva, Switzerland: World Health Organization, 1996 (publication no.ST/ESA/245).

4. Educational Development, Inc. Northeast injury prevention network suicide databook. Children's Safety Network Injury Data Technical Assistance Center, San Diego, California: 2000.

5. Spicer RS, Miller TR. Suicide acts in 8 states: incidence and case fatality rates by demographics and method. Am J Public Health 2000;90:1885-91. 
6. Eisele JW, Frigino J, Haglund W, Reay DT. Teenage suicide in King County, Washington: comparison with adult suicides. Am J Forensic Med Pathol 1987;8:214.

7. CDC. Fatal and nonfatal suicide attempts among adolescentsOregon, 1988-1993. MMWR 1995;48:312-5.

8. Rausch TK, Sanddal ND, Sanddal TL, Esposito TJ. Changing epidemiology of injury-related pediatric mortality in a rural state: implications for injury control. Pediatr Emerg Care 1998;14:390-1.

9. Hsaio AK, Hedges JR. Role of the emergency medical services system in regionwide health monitoring and referral. Ann Emerg Med 1993;22:1696-702.

10. Hoyert DL, Arias E, Smith BL, Murphy SL, Kochanek KD. Deaths: final data for 1999. National vital statistics report. Hyattsville, Maryland: National Center for Health Statistics; vol 49, no. 8.

\section{Notice to Readers}

\section{Evaluation of Postexposure Antibiotic Prophylaxis to Prevent Anthrax}

In response to the recent bioterrorist attacks associated with intentional release of Bacillus anthracis, approximately 10,000 persons potentially exposed to anthrax in Connecticut, Florida, New Jersey, New York City, and Washington, D.C., were recommended to take at least 60 days of postexposure antibiotic prophylaxis. Surveillance for adverse events and adherence to antibiotics has been conducted through surveillance and cross-sectional studies. CDC is evaluating the program to distribute antimicrobial agents and assessing adverse events and adherence. The objectives of this evaluation are to assess the provision of antimicrobial agents and educational materials to affected persons, to determine adverse events associated with the antimicrobial agents, and to characterize adherence to the recommended regimen. The information from this evaluation will be critical to CDC's effort to improve the technical assistance and supplies needed with future anthrax postexposure prophylaxis campaigns and to comply with Food and Drug Administration regulations for monitoring for adverse events.

CDC has contracted RTI International to conduct brief telephone interviews of all persons for whom postexposure antibiotic prophylaxis was recommended. Interviews are scheduled to begin in late January 2002 and will continue for approximately 8 weeks. Additional information about the program evaluation is available from CDC, telephone 404639-3158. 
FIGURE I. Selected notifiable disease reports, United States, comparison of provisional 4-week totals ending January 19, 2002, with historical data

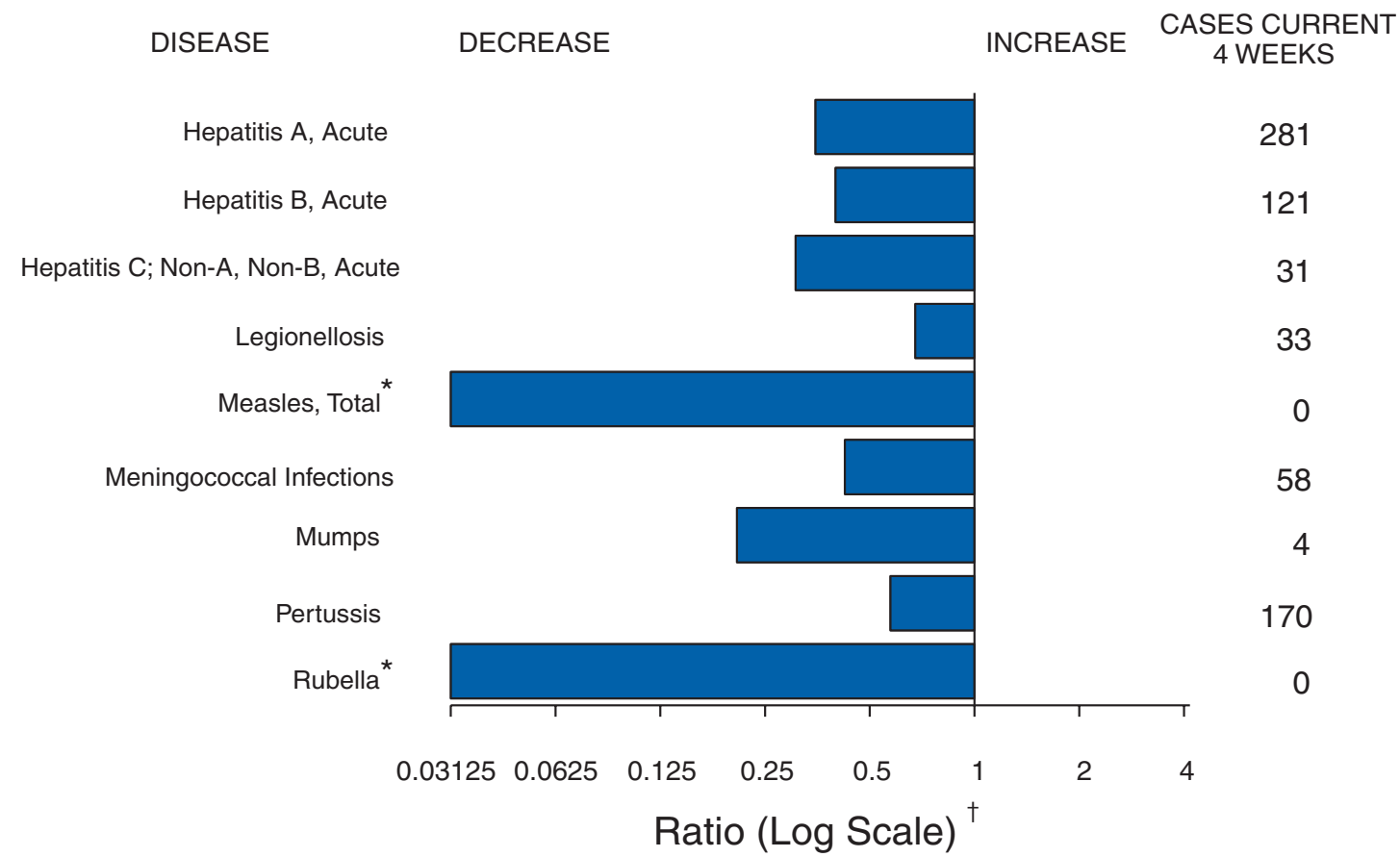

* No measles or rubella cases were reported for the current 4-week period yielding a ratio for week 3 of zero (0).

† Ratio of current 4-week total to mean of 154 -week totals (from previous, comparable, and subsequent 4-week periods for the past 5 years). The point where the hatched area begins is based on the mean and two standard deviations of these 4-week totals.

TABLE I. Summary of provisional cases of selected notifiable diseases, United States, cumulative, week ending January 19, 2002 (3rd Week)*

Anthrax

Botulism:

foodborne

infant

other (wound \& unspecified)

Brucellosis

Chancroid

Cholera

Cyclosporiasis $^{\dagger}$

Diphtheria

Ehrlichiosis:

human granulocytic (HGE) ${ }^{\dagger}$ human monocytic (HME) ${ }^{\dagger}$ other and unspecified

Encephalitis: California serogroup viral ${ }^{\dagger}$ eastern equine ${ }^{\dagger}$

Powassan $^{\dagger}$

St. Louis ${ }^{\dagger}$ western equine ${ }^{\dagger}$
Encephalitis: $\quad$ West Nile $^{\dagger}$

Hansen disease (leprosy) ${ }^{\dagger}$

Hantavirus pulmonary syndrome ${ }^{\dagger}$

Hemolytic uremic syndrome, postdiarrheal ${ }^{\dagger}$

HIV infection, pediatric ${ }^{\text {t\$ }}$

Plague

Poliomyelitis, paralytic

Psittacosis $^{\dagger}$

$Q$ fever $^{\dagger}$

Rabies, human

Streptococcal toxic-shock syndrome ${ }^{\dagger}$

Tetanus

Toxic-shock syndrome

Trichinosis

Tularemia

Yellow fever

\begin{tabular}{|c|c}
$\begin{array}{c}\text { Cum. } \\
\mathbf{2 0 0 2}\end{array}$ & $\begin{array}{c}\text { Cum. } \\
\mathbf{2 0 0 1}\end{array}$ \\
\hline 3 & - \\
1 & 2 \\
- & - \\
6 & 4 \\
- & - \\
- & - \\
- & - \\
- & - \\
2 & - \\
- & - \\
1 & 4 \\
- & 4 \\
5 & 8 \\
- & 2 \\
3 & 1 \\
- & - \\
\hline
\end{tabular}

-:No reported cases.

* Incidence data for reporting year 2001 and 2002 are provisional and cumulative (year-to-date).

† Not notifiable in all states.

$\S$ Updated monthly from reports to the Division of HIV/AIDS Prevention — Surveillance and Epidemiology, National Center for HIV, STD, and TB Prevention (NCHSTP). Last update December 25, 2001. 
TABLE II. Provisional cases of selected notifiable diseases, United States, weeks ending January 19, 2002, and January 20, 2001 (3rd Week)*

\begin{tabular}{|c|c|c|c|c|c|c|c|c|c|c|}
\hline \multirow[b]{3}{*}{ Reporting Area } & \multirow{2}{*}{\multicolumn{2}{|c|}{ AIDS }} & \multirow{2}{*}{\multicolumn{2}{|c|}{ Chlamydia $^{\dagger}$}} & \multirow{2}{*}{\multicolumn{2}{|c|}{ Cryptosporidiosis }} & \multicolumn{4}{|c|}{ Escherichia coli } \\
\hline & & & & & & & \multicolumn{2}{|c|}{ 0157:H7 } & \multicolumn{2}{|c|}{$\begin{array}{l}\text { Shiga Toxin Positive, } \\
\text { Serogroup non-0157 }\end{array}$} \\
\hline & $\begin{array}{l}\text { Cum. } \\
2002^{\S}\end{array}$ & $\begin{array}{l}\text { Cum. } \\
2001\end{array}$ & $\begin{array}{l}\text { Cum. } \\
2002\end{array}$ & $\begin{array}{l}\text { Cum. } \\
2001\end{array}$ & $\begin{array}{l}\text { Cum. } \\
2002\end{array}$ & $\begin{array}{l}\text { Cum. } \\
2001\end{array}$ & $\begin{array}{l}\text { Cum. } \\
2002\end{array}$ & $\begin{array}{l}\text { Cum. } \\
2001\end{array}$ & $\begin{array}{l}\text { Cum. } \\
2002 \\
\end{array}$ & $\begin{array}{l}\text { Cum. } \\
2001\end{array}$ \\
\hline UNITED STATES & - & - & 21,567 & 34,730 & 60 & 80 & 45 & 38 & 3 & 2 \\
\hline $\begin{array}{l}\text { NEW ENGLAND } \\
\text { Maine } \\
\text { N.H. } \\
\text { Vt. } \\
\text { Mass. } \\
\text { R.I. } \\
\text { Conn. }\end{array}$ & $\begin{array}{l}- \\
- \\
- \\
- \\
-\end{array}$ & $\begin{array}{l}- \\
- \\
- \\
- \\
- \\
- \\
-\end{array}$ & $\begin{array}{r}693 \\
64 \\
39 \\
51 \\
382 \\
157 \\
-\end{array}$ & $\begin{array}{r}770 \\
57 \\
60 \\
24 \\
126 \\
136 \\
367\end{array}$ & $\begin{array}{l}- \\
- \\
- \\
- \\
- \\
- \\
-\end{array}$ & $\begin{array}{l}2 \\
- \\
- \\
2 \\
- \\
- \\
-\end{array}$ & $\begin{array}{l}7 \\
- \\
- \\
- \\
4 \\
- \\
3\end{array}$ & $\begin{array}{l}5 \\
- \\
- \\
- \\
5 \\
- \\
-\end{array}$ & $\begin{array}{l}- \\
- \\
- \\
- \\
-\end{array}$ & $\begin{array}{l}- \\
- \\
- \\
- \\
-\end{array}$ \\
\hline $\begin{array}{l}\text { MID. ATLANTIC } \\
\text { Upstate N.Y. } \\
\text { N.Y. City } \\
\text { N.J. } \\
\text { Pa. }\end{array}$ & $\begin{array}{l}- \\
- \\
- \\
-\end{array}$ & $\begin{array}{l}- \\
- \\
- \\
- \\
-\end{array}$ & $\begin{array}{r}1,867 \\
168 \\
1,034 \\
- \\
665\end{array}$ & $\begin{array}{r}2,388 \\
143 \\
1,215 \\
322 \\
708\end{array}$ & $\begin{array}{l}7 \\
2 \\
1 \\
- \\
4\end{array}$ & $\begin{array}{l}9 \\
- \\
7 \\
2 \\
-\end{array}$ & $\begin{array}{r}4 \\
4 \\
- \\
- \\
\mathrm{N}\end{array}$ & $\begin{array}{r}4 \\
4 \\
- \\
- \\
\mathrm{N}\end{array}$ & $\begin{array}{l}- \\
- \\
- \\
-\end{array}$ & $\begin{array}{l}- \\
- \\
-\end{array}$ \\
\hline $\begin{array}{l}\text { E.N. CENTRAL } \\
\text { Ohio } \\
\text { Ind. } \\
\text { III. } \\
\text { Mich. } \\
\text { Wis. }\end{array}$ & $\begin{array}{l}- \\
- \\
- \\
- \\
-\end{array}$ & $\begin{array}{l}- \\
- \\
- \\
- \\
- \\
-\end{array}$ & $\begin{array}{r}3,173 \\
196 \\
174 \\
950 \\
1,664 \\
189\end{array}$ & $\begin{array}{r}6,891 \\
2,249 \\
633 \\
2,190 \\
903 \\
916\end{array}$ & $\begin{array}{r}10 \\
3 \\
- \\
- \\
4 \\
3\end{array}$ & $\begin{array}{r}31 \\
4 \\
1 \\
3 \\
4 \\
19\end{array}$ & $\begin{array}{l}7 \\
5 \\
1 \\
1 \\
- \\
-\end{array}$ & $\begin{array}{l}5 \\
1 \\
- \\
3 \\
- \\
1\end{array}$ & $\begin{array}{l}- \\
- \\
- \\
- \\
-\end{array}$ & $\begin{array}{l}- \\
- \\
- \\
- \\
-\end{array}$ \\
\hline $\begin{array}{l}\text { W.N. CENTRAL } \\
\text { Minn. } \\
\text { lowa } \\
\text { Mo. } \\
\text { N. Dak. } \\
\text { S. Dak. } \\
\text { Nebr. } \\
\text { Kans. }\end{array}$ & $\begin{array}{l}- \\
- \\
- \\
- \\
- \\
-\end{array}$ & $\begin{array}{l}- \\
- \\
- \\
- \\
- \\
- \\
-\end{array}$ & $\begin{array}{r}306 \\
169 \\
- \\
29 \\
13 \\
95 \\
- \\
-\end{array}$ & $\begin{array}{r}1,793 \\
480 \\
73 \\
656 \\
46 \\
106 \\
122 \\
310\end{array}$ & $\begin{array}{l}4 \\
1 \\
1 \\
2 \\
- \\
- \\
- \\
-\end{array}$ & $\begin{array}{l}3 \\
- \\
1 \\
- \\
- \\
- \\
2 \\
-\end{array}$ & $\begin{array}{l}8 \\
2 \\
3 \\
1 \\
- \\
- \\
- \\
2\end{array}$ & $\begin{array}{l}2 \\
1 \\
- \\
- \\
- \\
1 \\
- \\
-\end{array}$ & $\begin{array}{l}2 \\
2 \\
- \\
- \\
- \\
- \\
- \\
-\end{array}$ & $\begin{array}{l}- \\
- \\
- \\
- \\
- \\
- \\
-\end{array}$ \\
\hline $\begin{array}{l}\text { S. ATLANTIC } \\
\text { Del. } \\
\text { Md. } \\
\text { D.C. } \\
\text { Va. } \\
\text { W.Va. } \\
\text { N.C. } \\
\text { S.C. } \\
\text { Ga. } \\
\text { Fla. }\end{array}$ & $\begin{array}{l}- \\
- \\
- \\
- \\
- \\
- \\
- \\
- \\
-\end{array}$ & $\begin{array}{l}- \\
- \\
- \\
- \\
- \\
- \\
- \\
- \\
- \\
-\end{array}$ & $\begin{array}{r}4,145 \\
131 \\
748 \\
77 \\
648 \\
106 \\
457 \\
292 \\
353 \\
1,333\end{array}$ & $\begin{array}{r}6,353 \\
165 \\
712 \\
175 \\
740 \\
110 \\
739 \\
1,359 \\
1,000 \\
1,353\end{array}$ & $\begin{array}{r}23 \\
- \\
1 \\
1 \\
- \\
- \\
2 \\
- \\
19 \\
-\end{array}$ & $\begin{array}{l}6 \\
- \\
1 \\
1 \\
1 \\
- \\
- \\
- \\
2 \\
1\end{array}$ & $\begin{array}{r}11 \\
- \\
- \\
1 \\
- \\
- \\
1 \\
- \\
9 \\
-\end{array}$ & $\begin{array}{l}4 \\
- \\
- \\
- \\
- \\
- \\
2 \\
1 \\
1 \\
-\end{array}$ & $\begin{array}{l}1 \\
- \\
- \\
- \\
- \\
- \\
- \\
- \\
1 \\
-\end{array}$ & $\begin{array}{l}1 \\
- \\
- \\
- \\
1 \\
- \\
- \\
- \\
- \\
-\end{array}$ \\
\hline $\begin{array}{l}\text { E.S. CENTRAL } \\
\text { Ky. } \\
\text { Tenn. } \\
\text { Ala. } \\
\text { Miss. }\end{array}$ & $\begin{array}{l}- \\
- \\
- \\
-\end{array}$ & $\begin{array}{l}- \\
- \\
- \\
-\end{array}$ & $\begin{array}{r}2,527 \\
417 \\
1,013 \\
837 \\
260\end{array}$ & $\begin{array}{r}2,321 \\
343 \\
662 \\
640 \\
676\end{array}$ & $\begin{array}{l}1 \\
1 \\
- \\
- \\
-\end{array}$ & $\begin{array}{l}2 \\
- \\
- \\
1 \\
1\end{array}$ & $\begin{array}{l}- \\
- \\
- \\
-\end{array}$ & $\begin{array}{l}2 \\
- \\
2 \\
- \\
-\end{array}$ & $\begin{array}{l}- \\
- \\
-\end{array}$ & $\begin{array}{l}- \\
- \\
-\end{array}$ \\
\hline $\begin{array}{l}\text { W.S. CENTRAL } \\
\text { Ark. } \\
\text { La. } \\
\text { Okla. } \\
\text { Tex. }\end{array}$ & $\begin{array}{l}- \\
- \\
- \\
-\end{array}$ & $\begin{array}{l}- \\
- \\
- \\
-\end{array}$ & $\begin{array}{r}4,358 \\
- \\
837 \\
577 \\
2,944\end{array}$ & $\begin{array}{r}5,799 \\
540 \\
970 \\
498 \\
3,791\end{array}$ & $\begin{array}{l}1 \\
1 \\
- \\
- \\
-\end{array}$ & $\begin{array}{l}2 \\
- \\
1 \\
1 \\
-\end{array}$ & $\begin{array}{l}- \\
- \\
- \\
-\end{array}$ & $\begin{array}{l}3 \\
- \\
- \\
- \\
3\end{array}$ & $\begin{array}{l}- \\
- \\
-\end{array}$ & $\begin{array}{l}- \\
- \\
-\end{array}$ \\
\hline $\begin{array}{l}\text { MOUNTAIN } \\
\text { Mont. } \\
\text { Idaho } \\
\text { Wyo. } \\
\text { Colo. } \\
\text { N. Mex. } \\
\text { Ariz. } \\
\text { Utah } \\
\text { Nev. }\end{array}$ & $\begin{array}{l}- \\
- \\
- \\
- \\
- \\
- \\
- \\
-\end{array}$ & $\begin{array}{l}- \\
- \\
- \\
- \\
- \\
- \\
- \\
- \\
-\end{array}$ & $\begin{array}{r}1,304 \\
63 \\
114 \\
31 \\
262 \\
135 \\
563 \\
136 \\
-\end{array}$ & $\begin{array}{r}1,900 \\
13 \\
113 \\
45 \\
658 \\
262 \\
501 \\
33 \\
275\end{array}$ & $\begin{array}{l}3 \\
- \\
1 \\
- \\
- \\
- \\
- \\
2 \\
-\end{array}$ & $\begin{array}{l}7 \\
- \\
- \\
- \\
3 \\
2 \\
1 \\
1 \\
-\end{array}$ & $\begin{array}{l}- \\
- \\
- \\
- \\
- \\
- \\
- \\
-\end{array}$ & $\begin{array}{l}4 \\
- \\
2 \\
- \\
1 \\
- \\
1 \\
- \\
-\end{array}$ & $\begin{array}{l}- \\
- \\
- \\
- \\
- \\
- \\
- \\
- \\
-\end{array}$ & $\begin{array}{l}1 \\
- \\
- \\
- \\
1 \\
- \\
- \\
- \\
-\end{array}$ \\
\hline $\begin{array}{l}\text { PACIFIC } \\
\text { Wash. } \\
\text { Oreg. } \\
\text { Calif. } \\
\text { Alaska } \\
\text { Hawaii }\end{array}$ & $\begin{array}{l}- \\
- \\
- \\
- \\
-\end{array}$ & $\begin{array}{l}- \\
- \\
- \\
- \\
- \\
-\end{array}$ & $\begin{array}{r}3,194 \\
704 \\
- \\
2,330 \\
98 \\
62\end{array}$ & $\begin{array}{r}6,515 \\
756 \\
285 \\
5,172 \\
76 \\
226\end{array}$ & $\begin{array}{r}11 \\
- \\
5 \\
6 \\
- \\
-\end{array}$ & $\begin{array}{r}18 \\
U \\
1 \\
17 \\
- \\
-\end{array}$ & $\begin{array}{l}8 \\
- \\
5 \\
3 \\
- \\
-\end{array}$ & $\begin{array}{l}9 \\
- \\
- \\
7 \\
- \\
2\end{array}$ & $\begin{array}{l}- \\
- \\
- \\
- \\
-\end{array}$ & $\begin{array}{l}- \\
- \\
- \\
- \\
-\end{array}$ \\
\hline $\begin{array}{l}\text { Guam } \\
\text { P.R. } \\
\text { V.I. } \\
\text { Amer. Samoa } \\
\text { C.N.M.I. }\end{array}$ & $\begin{array}{l}- \\
- \\
\\
\end{array}$ & $\begin{array}{l}- \\
- \\
\\
U\end{array}$ & $\begin{array}{r}- \\
- \\
\\
11\end{array}$ & $\begin{array}{r}- \\
147 \\
7 \\
\cup \\
U\end{array}$ & $\begin{array}{l}- \\
- \\
\bar{U} \\
-\end{array}$ & $\begin{array}{l}- \\
- \\
U\end{array}$ & $\begin{array}{l}N \\
- \\
\\
-\end{array}$ & $\begin{array}{l}N \\
- \\
U \\
U\end{array}$ & $\begin{array}{l}- \\
\\
\end{array}$ & $\begin{array}{l}- \\
\\
U\end{array}$ \\
\hline
\end{tabular}

N: Not notifiable. U: Unavailable. $\quad-:$ No reported cases. $\quad$ C.N.M.I.: Commonwealth of Northern Mariana Islands.

* Incidence data for reporting year 2001 and 2002 are provisional and cumulative (year-to-date).

* Incidence data for reporting year 2001 and 2002 are provisional and

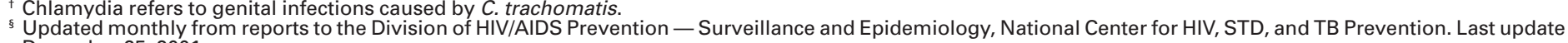
December 25, 2001. 
TABLE II. (Cont'd) Provisional cases of selected notifiable diseases, United States, weeks ending January 19, 2002, and January 20, 2001 (3rd Week) $)^{\star}$

\begin{tabular}{|c|c|c|c|c|c|c|c|c|c|}
\hline \multirow[b]{4}{*}{ Reporting Area } & \multirow{2}{*}{\multicolumn{2}{|c|}{ Escherichia coli }} & \multirow{4}{*}{$\begin{array}{l}\text { Giardiasis } \\
\text { Cum. } \\
2002\end{array}$} & \multirow{3}{*}{\multicolumn{2}{|c|}{ Gonorrhea }} & \multicolumn{4}{|c|}{$\begin{array}{c}\text { Haemophilus influenzae, } \\
\text { Invasive }\end{array}$} \\
\hline & & & & & & \multirow{2}{*}{\multicolumn{2}{|c|}{$\begin{array}{c}\text { All Ages, } \\
\text { All Serotypes }\end{array}$}} & \multirow{2}{*}{\multicolumn{2}{|c|}{$\begin{array}{c}\text { Age }<5 \text { years } \\
\text { Serotype } \\
\text { B }\end{array}$}} \\
\hline & \multicolumn{2}{|c|}{$\begin{array}{c}\text { Shiga Toxin Positive, } \\
\text { Not Serogrouped }\end{array}$} & & & & & & & \\
\hline & $\begin{array}{l}\text { Cum. } \\
2002\end{array}$ & 2001 & & $\begin{array}{r}\text { Cum. } \\
2002 \\
\end{array}$ & $\begin{array}{l}\text { Cum. } \\
2001\end{array}$ & $\begin{array}{l}\text { Cum. } \\
2002 \\
\end{array}$ & $\begin{array}{r}\text { Cum. } \\
2001\end{array}$ & $\begin{array}{l}\text { Cum. } \\
2002 \\
\end{array}$ & $\begin{array}{l}\text { Cum. } \\
2001\end{array}$ \\
\hline UNITED STATES & - & 1 & 329 & 10,521 & 17,888 & 42 & 53 & - & - \\
\hline NEW ENGLAND & - & - & 23 & 213 & 210 & - & 2 & - & - \\
\hline Maine & - & - & 10 & 5 & 1 & - & - & - & - \\
\hline N.H. & - & - & 1 & 4 & 4 & - & - & - & - \\
\hline Vt. & - & - & 6 & 5 & 10 & - & - & - & - \\
\hline Mass. & - & - & 4 & 155 & 40 & - & 2 & - & - \\
\hline R.I. & - & - & - & 44 & 38 & - & - & - & - \\
\hline Conn. & - & - & 2 & - & 117 & - & - & - & - \\
\hline MID. ATLANTIC & - & - & 55 & 860 & 1,441 & 13 & 16 & - & - \\
\hline Upstate N.Y. & - & - & 16 & 107 & 119 & 6 & 4 & - & - \\
\hline N.Y. City & - & - & 7 & 491 & 585 & 5 & 4 & - & - \\
\hline N.J. & - & - & - & - & 274 & - & 8 & - & - \\
\hline Pa. & - & - & 32 & 262 & 463 & 2 & - & - & - \\
\hline E.N. CENTRAL & - & - & 83 & 1,643 & 3,605 & 10 & 11 & - & - \\
\hline Ohio & - & - & 41 & 151 & 1,265 & 10 & 4 & - & - \\
\hline Ind. & - & - & - & 84 & 325 & - & - & - & - \\
\hline IIII. & - & - & 11 & 547 & 1,218 & - & 4 & - & - \\
\hline Mich. & - & - & 27 & 818 & 439 & - & 1 & - & - \\
\hline Wis. & - & - & 4 & 43 & 358 & - & 2 & - & - \\
\hline W.N. CENTRAL & - & - & 32 & 98 & 834 & - & 1 & - & - \\
\hline Minn. & - & - & 4 & 70 & 167 & - & - & - & - \\
\hline lowa & - & - & 7 & & 12 & - & - & - & - \\
\hline & - & - & 12 & 15 & 419 & - & 1 & - & - \\
\hline N. Dak. & - & - & - & - & 1 & - & - & - & - \\
\hline S. Dak. & - & - & 3 & 13 & 14 & - & - & - & - \\
\hline Nebr. & - & - & - & - & 59 & - & - & - & - \\
\hline Kans. & - & - & 6 & - & 162 & - & - & - & - \\
\hline S. ATLANTIC & - & - & 51 & 2,756 & 4,735 & 13 & 17 & - & - \\
\hline Del. & - & - & 4 & 114 & 73 & - & - & - & - \\
\hline & - & - & 8 & 436 & 509 & 3 & - & - & - \\
\hline D.C. & - & - & 5 & 92 & 187 & - & - & - & - \\
\hline & - & - & - & 414 & 332 & - & 1 & - & - \\
\hline W. va. & - & - & - & 40 & 21 & - & 1 & - & - \\
\hline N.C. & - & - & - & 378 & 796 & 3 & 5 & - & - \\
\hline S.C. & - & - & - & 252 & 1,377 & - & - & - & - \\
\hline Ga. & - & - & 34 & 269 & 625 & 7 & 7 & - & - \\
\hline Fla. & - & - & - & 761 & 815 & - & 3 & - & - \\
\hline E.S. CENTRAL & - & 1 & 11 & 1,590 & 1,820 & - & 1 & - & - \\
\hline Ky. & - & 1 & - & 187 & 172 & - & - & - & - \\
\hline Tenn. & - & - & 3 & 628 & 554 & - & - & - & - \\
\hline Ala. & - & - & 8 & 592 & 625 & - & 1 & - & - \\
\hline Miss. & - & - & - & 183 & 469 & - & - & - & - \\
\hline W.S. CENTRAL & - & - & 4 & 2,212 & 3,025 & - & - & - & - \\
\hline Ark. & - & - & 4 & & 380 & - & - & - & - \\
\hline La. & - & - & - & 626 & 703 & - & - & - & - \\
\hline Okla. & - & - & - & 252 & 245 & - & - & - & - \\
\hline Tex. & - & - & - & 1,334 & 1,697 & - & - & - & - \\
\hline MOUNTAIN & - & - & 30 & 369 & 599 & 1 & 4 & - & - \\
\hline Mont. & - & - & 1 & 5 & 1 & - & - & - & - \\
\hline Idaho & - & - & 1 & 6 & 7 & - & - & - & - \\
\hline Wyo. & - & - & - & 3 & 7 & - & - & - & - \\
\hline Colo. & - & - & 22 & 124 & 254 & 1 & 2 & - & - \\
\hline N. Mex. & - & - & 5 & 25 & 63 & - & 2 & - & - \\
\hline Ariz. & - & - & - & 198 & 162 & - & - & - & - \\
\hline Utah & - & - & 1 & 8 & 2 & - & - & - & - \\
\hline Nev. & - & - & - & - & 103 & - & - & - & - \\
\hline PACIFIC & - & - & 40 & 780 & 1,619 & 5 & 1 & - & - \\
\hline Wash. & - & - & 4 & 180 & 164 & - & - & - & - \\
\hline Oreg. & - & - & 31 & & 52 & 3 & - & - & - \\
\hline Calif. & - & - & - & 571 & 1,357 & - & 1 & - & - \\
\hline Alaska & - & - & 1 & 16 & 13 & - & - & - & - \\
\hline Hawaii & - & - & 4 & 13 & 33 & 2 & - & - & - \\
\hline Guam & - & - & - & - & - & - & - & - & - \\
\hline & - & - & - & - & 61 & - & - & - & - \\
\hline V.I. & - & - & - & - & & - & - & - & - \\
\hline Amer. Samoa & $\mathrm{U}$ & U & U & U & U & U & U & U & U \\
\hline $\begin{array}{l}\text { C.N.M.I. } \\
\text { Ca }\end{array}$ & - & U & - & - & u & - & u & - & u \\
\hline
\end{tabular}

$\mathrm{N}$ : Not notifiable. $\quad$ U: Unavailable. $\quad-:$ No reported cases.

* Incidence data for reporting year 2001 and 2002 are provisional and cumulative (year-to-date). 
TABLE II. (Cont'd) Provisional cases of selected notifiable diseases, United States, weeks ending January 19, 2002, and January 20, 2001 (3rd Week) $)^{\star}$

\begin{tabular}{|c|c|c|c|c|c|c|c|c|c|c|}
\hline \multirow[b]{4}{*}{ Reporting Area } & \multicolumn{4}{|c|}{ Haemophilus influenzae, Invasive } & & & & & & \\
\hline & \multicolumn{4}{|c|}{ Age $<5$ years } & \multicolumn{6}{|c|}{ Hepatitis (Viral, Acute), by Type } \\
\hline & \multicolumn{2}{|c|}{ Non-Serotype B } & \multicolumn{2}{|c|}{ Unknown Serotype } & \multicolumn{2}{|c|}{$\mathbf{A}$} & \multicolumn{2}{|c|}{ B } & \multicolumn{2}{|c|}{ C; Non-A, Non-B } \\
\hline & $\begin{array}{l}\text { Cum. } \\
2002\end{array}$ & $\begin{array}{r}\text { Cum. } \\
2001\end{array}$ & $\begin{array}{c}\text { Cum. } \\
2002\end{array}$ & $\begin{array}{r}\text { Cum. } \\
2001\end{array}$ & $\begin{array}{r}\text { Cum. } \\
2002 \\
\end{array}$ & $\begin{array}{r}\text { Cum. } \\
2001\end{array}$ & $\begin{array}{r}\text { Cum. } \\
2002\end{array}$ & $\begin{array}{r}\text { Cum. } \\
2001\end{array}$ & $\begin{array}{r}\text { Cum. } \\
2002\end{array}$ & $\begin{array}{l}\text { Cum. } \\
2001\end{array}$ \\
\hline UNITED STATES & 2 & 16 & - & 1 & 235 & 602 & 96 & 242 & 24 & 301 \\
\hline $\begin{array}{l}\text { NEW ENGLAND } \\
\text { Maine } \\
\text { N.H. } \\
\text { Vt. } \\
\text { Mass. } \\
\text { R.I. } \\
\text { Conn. }\end{array}$ & $\begin{array}{l}- \\
- \\
- \\
- \\
-\end{array}$ & $\begin{array}{l}1 \\
- \\
- \\
- \\
1 \\
- \\
-\end{array}$ & $\begin{array}{l}- \\
- \\
- \\
- \\
-\end{array}$ & $\begin{array}{l}- \\
- \\
- \\
- \\
-\end{array}$ & $\begin{array}{l}7 \\
1 \\
- \\
- \\
1 \\
- \\
5\end{array}$ & $\begin{array}{r}27 \\
- \\
1 \\
- \\
14 \\
- \\
12\end{array}$ & $\begin{array}{l}2 \\
- \\
- \\
1 \\
- \\
1 \\
-\end{array}$ & $\begin{array}{l}4 \\
- \\
- \\
1 \\
- \\
- \\
3\end{array}$ & $\begin{array}{l}- \\
- \\
- \\
- \\
-\end{array}$ & $\begin{array}{l}4 \\
- \\
- \\
1 \\
3 \\
- \\
-\end{array}$ \\
\hline $\begin{array}{l}\text { MID. ATLANTIC } \\
\text { Upstate N.Y. } \\
\text { N.Y. City } \\
\text { N.J. } \\
\text { Pa. }\end{array}$ & $\begin{array}{l}- \\
- \\
-\end{array}$ & $\begin{array}{l}1 \\
- \\
1 \\
- \\
-\end{array}$ & $\begin{array}{l}- \\
- \\
- \\
-\end{array}$ & $\begin{array}{l}- \\
- \\
- \\
-\end{array}$ & $\begin{array}{r}18 \\
1 \\
2 \\
- \\
15\end{array}$ & $\begin{array}{r}65 \\
5 \\
25 \\
32 \\
3\end{array}$ & $\begin{array}{l}7 \\
1 \\
1 \\
- \\
5\end{array}$ & $\begin{array}{r}61 \\
- \\
26 \\
30 \\
5\end{array}$ & $\begin{array}{l}2 \\
1 \\
- \\
- \\
1\end{array}$ & $\begin{array}{r}119 \\
- \\
- \\
118 \\
1\end{array}$ \\
\hline $\begin{array}{l}\text { E.N. CENTRAL } \\
\text { Ohio } \\
\text { Ind. } \\
\text { III. } \\
\text { Mich. } \\
\text { Wis. }\end{array}$ & $\begin{array}{l}- \\
- \\
- \\
-\end{array}$ & $\begin{array}{l}3 \\
- \\
- \\
2 \\
- \\
1\end{array}$ & $\begin{array}{l}- \\
- \\
- \\
- \\
-\end{array}$ & $\begin{array}{l}- \\
- \\
- \\
-\end{array}$ & $\begin{array}{r}17 \\
7 \\
- \\
3 \\
7 \\
-\end{array}$ & $\begin{array}{r}142 \\
9 \\
- \\
99 \\
30 \\
4\end{array}$ & $\begin{array}{r}23 \\
5 \\
- \\
- \\
18 \\
-\end{array}$ & $\begin{array}{r}30 \\
6 \\
- \\
- \\
24 \\
-\end{array}$ & $\begin{array}{l}2 \\
1 \\
- \\
- \\
1 \\
-\end{array}$ & $\begin{array}{r}19 \\
- \\
8 \\
11 \\
-\end{array}$ \\
\hline $\begin{array}{l}\text { W.N. CENTRAL } \\
\text { Minn. } \\
\text { lowa } \\
\text { Mo. } \\
\text { N. Dak. } \\
\text { S. Dak. } \\
\text { Nebr. } \\
\text { Kans. }\end{array}$ & $\begin{array}{l}- \\
- \\
- \\
- \\
- \\
-\end{array}$ & $\begin{array}{l}- \\
- \\
- \\
- \\
- \\
-\end{array}$ & $\begin{array}{l}- \\
- \\
- \\
- \\
- \\
-\end{array}$ & $\begin{array}{l}- \\
- \\
- \\
- \\
- \\
-\end{array}$ & $\begin{array}{r}15 \\
- \\
5 \\
2 \\
- \\
1 \\
- \\
7\end{array}$ & $\begin{array}{r}37 \\
- \\
1 \\
11 \\
- \\
- \\
13 \\
12\end{array}$ & $\begin{array}{l}3 \\
1 \\
1 \\
- \\
- \\
- \\
- \\
1\end{array}$ & $\begin{array}{r}10 \\
- \\
8 \\
8 \\
1 \\
1 \\
-\end{array}$ & $\begin{array}{r}13 \\
- \\
- \\
13 \\
- \\
- \\
- \\
-\end{array}$ & $\begin{array}{r}64 \\
- \\
- \\
63 \\
- \\
- \\
- \\
1\end{array}$ \\
\hline $\begin{array}{l}\text { S. ATLANTIC } \\
\text { Del. } \\
\text { Md. } \\
\text { D.C. } \\
\text { Va. } \\
\text { W. Va. } \\
\text { N.C. } \\
\text { S.C. } \\
\text { Ga. } \\
\text { Fla. }\end{array}$ & $\begin{array}{l}- \\
- \\
- \\
- \\
- \\
- \\
- \\
- \\
-\end{array}$ & $\begin{array}{l}2 \\
- \\
- \\
- \\
- \\
- \\
- \\
- \\
2 \\
-\end{array}$ & $\begin{array}{l}- \\
- \\
- \\
- \\
- \\
- \\
- \\
- \\
-\end{array}$ & $\begin{array}{l}- \\
- \\
- \\
- \\
- \\
- \\
- \\
-\end{array}$ & $\begin{array}{r}84 \\
- \\
25 \\
7 \\
- \\
- \\
20 \\
1 \\
31 \\
-\end{array}$ & $\begin{array}{r}55 \\
- \\
15 \\
1 \\
3 \\
- \\
4 \\
- \\
28 \\
4\end{array}$ & $\begin{array}{r}31 \\
- \\
6 \\
1 \\
- \\
- \\
11 \\
2 \\
11 \\
-\end{array}$ & $\begin{array}{r}37 \\
- \\
4 \\
1 \\
2 \\
- \\
8 \\
- \\
20 \\
2\end{array}$ & $\begin{array}{l}2 \\
1 \\
- \\
- \\
- \\
- \\
1 \\
- \\
- \\
-\end{array}$ & $\begin{array}{l}- \\
- \\
- \\
- \\
- \\
- \\
- \\
-\end{array}$ \\
\hline $\begin{array}{l}\text { E.S. CENTRAL } \\
\text { Ky. } \\
\text { Tenn. } \\
\text { Ala. } \\
\text { Miss. }\end{array}$ & $\begin{array}{l}- \\
- \\
- \\
-\end{array}$ & $\begin{array}{l}- \\
- \\
- \\
-\end{array}$ & $\begin{array}{l}- \\
- \\
-\end{array}$ & $\begin{array}{l}- \\
- \\
- \\
-\end{array}$ & $\begin{array}{l}5 \\
- \\
- \\
3 \\
2\end{array}$ & $\begin{array}{r}14 \\
1 \\
4 \\
9 \\
-\end{array}$ & $\begin{array}{l}2 \\
- \\
- \\
2 \\
-\end{array}$ & $\begin{array}{r}12 \\
3 \\
1 \\
2 \\
6\end{array}$ & $\begin{array}{l}1 \\
- \\
- \\
- \\
1\end{array}$ & $\begin{array}{r}14 \\
- \\
1 \\
- \\
13\end{array}$ \\
\hline $\begin{array}{l}\text { W.S. CENTRAL } \\
\text { Ark. } \\
\text { La. } \\
\text { Okla. } \\
\text { Tex. }\end{array}$ & $\begin{array}{l}- \\
- \\
- \\
-\end{array}$ & $\begin{array}{l}- \\
- \\
- \\
-\end{array}$ & $\begin{array}{l}- \\
- \\
- \\
-\end{array}$ & $\begin{array}{l}- \\
- \\
- \\
-\end{array}$ & $\begin{array}{r}5 \\
4 \\
- \\
- \\
1\end{array}$ & $\begin{array}{r}138 \\
3 \\
7 \\
3 \\
125\end{array}$ & $\begin{array}{l}7 \\
6 \\
- \\
- \\
1\end{array}$ & $\begin{array}{r}12 \\
2 \\
10 \\
- \\
-\end{array}$ & $\begin{array}{l}- \\
- \\
- \\
-\end{array}$ & $\begin{array}{r}77 \\
- \\
19 \\
58\end{array}$ \\
\hline $\begin{array}{l}\text { MOUNTAIN } \\
\text { Mont. } \\
\text { Idaho } \\
\text { Wyo. } \\
\text { Colo. } \\
\text { N. Mex. } \\
\text { Ariz. } \\
\text { Utah } \\
\text { Nev. }\end{array}$ & $\begin{array}{l}1 \\
- \\
- \\
- \\
- \\
1 \\
- \\
- \\
-\end{array}$ & $\begin{array}{l}2 \\
- \\
- \\
- \\
- \\
2 \\
- \\
- \\
-\end{array}$ & $\begin{array}{l}- \\
- \\
- \\
- \\
- \\
- \\
-\end{array}$ & $\begin{array}{l}1 \\
- \\
- \\
- \\
- \\
1 \\
- \\
- \\
-\end{array}$ & $\begin{array}{r}13 \\
1 \\
- \\
- \\
6 \\
3 \\
1 \\
2 \\
-\end{array}$ & $\begin{array}{r}29 \\
2 \\
2 \\
1 \\
11 \\
1 \\
6 \\
1 \\
5\end{array}$ & $\begin{array}{l}6 \\
- \\
- \\
- \\
3 \\
1 \\
- \\
2 \\
-\end{array}$ & $\begin{array}{r}18 \\
- \\
1 \\
- \\
8 \\
6 \\
1 \\
- \\
2\end{array}$ & $\begin{array}{l}2 \\
- \\
- \\
- \\
2 \\
- \\
- \\
- \\
-\end{array}$ & $\begin{array}{l}2 \\
- \\
- \\
2 \\
- \\
- \\
- \\
- \\
-\end{array}$ \\
\hline $\begin{array}{l}\text { PACIFIC } \\
\text { Wash. } \\
\text { Oreg. } \\
\text { Calif. } \\
\text { Alaska } \\
\text { Hawaii }\end{array}$ & $\begin{array}{l}1 \\
- \\
1 \\
- \\
-\end{array}$ & $\begin{array}{l}7 \\
- \\
- \\
6 \\
- \\
1\end{array}$ & $\begin{array}{l}- \\
- \\
- \\
-\end{array}$ & $\begin{array}{l}- \\
- \\
- \\
- \\
-\end{array}$ & $\begin{array}{r}71 \\
- \\
10 \\
61 \\
- \\
-\end{array}$ & $\begin{array}{r}95 \\
- \\
- \\
86 \\
8 \\
1\end{array}$ & $\begin{array}{r}15 \\
- \\
8 \\
7 \\
- \\
-\end{array}$ & $\begin{array}{r}58 \\
- \\
2 \\
53 \\
1 \\
2\end{array}$ & $\begin{array}{l}2 \\
- \\
2 \\
- \\
- \\
-\end{array}$ & $\begin{array}{l}2 \\
- \\
- \\
2 \\
- \\
-\end{array}$ \\
\hline $\begin{array}{l}\text { Guam } \\
\text { P.R. } \\
\text { V.I. } \\
\text { Amer. Samoa } \\
\text { C.N.M.I. }\end{array}$ & $\begin{array}{l}- \\
- \\
\text { U } \\
-\end{array}$ & $\begin{array}{l}- \\
\\
U\end{array}$ & $\begin{array}{l}- \\
\bar{U} \\
\end{array}$ & $\begin{array}{l}- \\
\\
U\end{array}$ & $\begin{array}{l}- \\
\\
\end{array}$ & $\begin{array}{l}- \\
\\
U\end{array}$ & $\begin{array}{l}- \\
- \\
\\
4\end{array}$ & $\begin{array}{c}- \\
1 \\
\\
U\end{array}$ & $\begin{array}{l}- \\
- \\
\text { U }\end{array}$ & $\begin{array}{l}- \\
- \\
U \\
U\end{array}$ \\
\hline
\end{tabular}

N: Not notifiable. U: Unavailable. $\quad-:$ No reported cases.

* Incidence data for reporting year 2001 and 2002 are provisional and cumulative (year-to-date). 
TABLE II. (Cont'd) Provisional cases of selected notifiable diseases, United States, weeks ending January 19, 2002, and January 20, 2001 $(3 \text { rd Week) })^{\star}$

\begin{tabular}{|c|c|c|c|c|c|c|c|c|c|c|}
\hline \multirow[b]{2}{*}{ Reporting Area } & \multicolumn{2}{|c|}{ Legionellosis } & \multicolumn{2}{|c|}{ Listeriosis } & \multicolumn{2}{|c|}{ Lyme Disease } & \multicolumn{2}{|c|}{ Malaria } & \multicolumn{2}{|c|}{$\begin{array}{c}\text { Measles } \\
\text { Total }\end{array}$} \\
\hline & $\begin{array}{r}\text { Cum. } \\
2002 \\
\end{array}$ & $\begin{array}{l}\text { Cum. } \\
2001 \\
\end{array}$ & $\begin{array}{l}\text { Cum. } \\
2002 \\
\end{array}$ & $\begin{array}{l}\text { Cum. } \\
2001 \\
\end{array}$ & $\begin{array}{l}\text { Cum. } \\
2002 \\
\end{array}$ & $\begin{array}{l}\text { Cum. } \\
2001 \\
\end{array}$ & $\begin{array}{r}\text { Cum. } \\
2002 \\
\end{array}$ & $\begin{array}{l}\text { Cum. } \\
2001 \\
\end{array}$ & $\begin{array}{r}\text { Cum. } \\
2002 \\
\end{array}$ & $\begin{array}{l}\text { Cum. } \\
2001 \\
\end{array}$ \\
\hline UNITED STATES & 26 & 31 & 9 & 19 & 127 & 131 & 24 & 46 & - & $6^{\dagger}$ \\
\hline NEW ENGLAND & - & 1 & 1 & 2 & 3 & 7 & 2 & 2 & - & - \\
\hline Maine & - & - & . & - & - & - & - & - & - & - \\
\hline N.H. & - & - & - & - & - & - & 1 & - & - & - \\
\hline Vt. & - & 1 & - & - & - & - & - & - & - & - \\
\hline Mass. & - & - & - & 2 & 3 & 7 & - & 2 & - & - \\
\hline R.I. & - & - & - & - & - & - & - & - & - & - \\
\hline Conn. & - & - & 1 & - & - & - & 1 & - & - & - \\
\hline MID. ATLANTIC & 3 & 2 & 2 & 2 & 85 & 73 & - & 13 & - & - \\
\hline Upstate N.Y. & - & - & 2 & 1 & 66 & 21 & - & 1 & - & - \\
\hline N.Y. City & - & - & . & 1 & - & 2 & - & 8 & - & - \\
\hline N.J. & - & 2 & . & - & - & 39 & - & 2 & - & - \\
\hline $\mathrm{Pa}$. & 3 & - & - & - & 19 & 11 & - & 2 & - & - \\
\hline E.N. CENTRAL & 18 & 17 & 2 & 4 & 2 & 17 & 4 & 5 & - & - \\
\hline Ohio & 13 & 9 & 2 & - & 2 & 7 & 2 & 1 & - & - \\
\hline Ind. & - & 1 & . & - & - & - & - & 1 & - & - \\
\hline & - & 3 & . & 1 & - & 2 & - & 3 & - & - \\
\hline Mich. & 5 & 2 & - & 2 & - & - & 2 & - & - & - \\
\hline Wis. & - & 2 & - & 1 & $\mathrm{U}$ & 8 & - & - & - & - \\
\hline W.N. CENTRAL & - & 3 & . & 1 & 3 & - & 3 & 1 & - & - \\
\hline Minn. & - & - & - & - & 1 & - & - & - & - & - \\
\hline lowa & - & - & - & - & - & - & 1 & - & - & - \\
\hline & - & 1 & . & - & 2 & - & 2 & 1 & - & - \\
\hline N. Dak. & - & - & - & - & - & - & - & - & - & - \\
\hline S. Dak. & - & - & . & - & - & - & - & - & - & - \\
\hline Nebr. & - & 1 & - & - & - & - & - & - & - & - \\
\hline Kans. & - & 1 & - & 1 & - & - & - & - & - & - \\
\hline S. ATLANTIC & 3 & 1 & . & 2 & 28 & 21 & 7 & 8 & - & - \\
\hline Del. & 1 & - & . & - & - & 1 & - & - & - & - \\
\hline Md. & 2 & 1 & - & 1 & 26 & 19 & 4 & 4 & - & - \\
\hline D.C. & - & - & - & - & 2 & 1 & 1 & 1 & - & - \\
\hline Va. & - & - & - & 1 & - & - & - & 2 & - & - \\
\hline W. Va. & $\mathrm{N}$ & $\mathrm{N}$ & - & - & - & - & - & - & - & - \\
\hline N.C. & - & - & . & - & - & - & 2 & 1 & - & - \\
\hline S.C. & - & - & - & - & - & - & - & - & - & - \\
\hline Ga. & - & - & - & - & - & - & - & - & - & - \\
\hline Fla. & - & - & - & - & - & - & - & - & - & - \\
\hline E.S. CENTRAL & - & 1 & . & 1 & - & 1 & - & - & - & - \\
\hline Ky. & - & - & - & 1 & - & 1 & - & - & - & - \\
\hline Tenn. & - & - & . & - & - & - & - & - & - & - \\
\hline Ala. & - & 1 & - & - & - & - & - & - & - & - \\
\hline Miss. & - & - & - & - & - & - & - & - & - & - \\
\hline W.S. CENTRAL & - & 1 & . & - & 1 & 8 & - & 2 & - & - \\
\hline & - & - & - & - & - & - & - & - & - & - \\
\hline La. & - & 1 & . & - & - & - & - & 1 & - & - \\
\hline Okla. & - & - & - & - & - & - & - & - & - & - \\
\hline Tex. & - & - & - & - & 1 & 8 & - & 1 & - & - \\
\hline MOUNTAIN & 1 & 1 & 1 & - & 1 & - & - & 2 & - & - \\
\hline Mont. & - & - & - & - & - & - & - & - & - & - \\
\hline Idaho & - & - & - & - & - & - & - & 1 & - & - \\
\hline Wyo. & - & - & . & - & - & - & - & - & - & - \\
\hline Colo. & - & 1 & 1 & - & 1 & - & - & 1 & - & - \\
\hline N. Mex. & - & - & . & - & - & - & - & - & - & - \\
\hline Ariz. & - & - & . & - & - & - & - & - & - & - \\
\hline Utah & 1 & - & - & - & - & - & - & - & - & - \\
\hline Nev. & - & - & - & - & - & - & - & - & - & - \\
\hline PACIFIC & 1 & 4 & 3 & 7 & 4 & 4 & 8 & 13 & - & 6 \\
\hline Wash. & - & - & . & - & - & - & - & - & - & 5 \\
\hline Oreg. & $\mathrm{N}$ & $\mathrm{N}$ & . & - & - & - & - & 2 & - & - \\
\hline Calif. & 1 & 4 & 3 & 7 & 4 & 4 & 6 & 11 & - & - \\
\hline Alaska & - & - & . & - & - & - & - & - & - & - \\
\hline Hawaii & - & - & - & - & N & $\mathrm{N}$ & 2 & - & - & 1 \\
\hline Guam & - & - & - & - & - & - & - & - & - & - \\
\hline & - & - & - & - & $\mathrm{N}$ & $\mathrm{N}$ & - & - & - & - \\
\hline & - & - & . & - & - & - & - & - & - & - \\
\hline Amer. Samoa & U & U & U & U & $U$ & U & U & U & U & U \\
\hline C.N.M.I. & - & U & . & U & - & U & - & U & - & U \\
\hline
\end{tabular}

N: Not notifiable.

U: Unavailable. 
TABLE II. (Cont'd) Provisional cases of selected notifiable diseases, United States, weeks ending January 19, 2002, and January 20, 2001 (3rd Week) $)^{*}$

\begin{tabular}{|c|c|c|c|c|c|c|c|c|}
\hline \multirow[b]{2}{*}{ Reporting Area } & \multicolumn{2}{|c|}{$\begin{array}{c}\text { Meningococcal } \\
\text { Disease }\end{array}$} & \multicolumn{2}{|c|}{ Mumps } & \multicolumn{2}{|c|}{ Pertussis } & \multicolumn{2}{|c|}{ Rabies, Animal } \\
\hline & $\begin{array}{l}\text { Cum. } \\
2002\end{array}$ & $\begin{array}{l}\text { Cum. } \\
2001\end{array}$ & $\begin{array}{l}\text { Cum. } \\
2002\end{array}$ & $\begin{array}{l}\text { Cum. } \\
2001\end{array}$ & $\begin{array}{l}\text { Cum. } \\
2002\end{array}$ & $\begin{array}{l}\text { Cum. } \\
2001\end{array}$ & $\begin{array}{l}\text { Cum. } \\
2002\end{array}$ & $\begin{array}{l}\text { Cum } \\
2001\end{array}$ \\
\hline UNITED STATES & 51 & 164 & 2 & 7 & 106 & 171 & 101 & 299 \\
\hline $\begin{array}{l}\text { NEW ENGLAND } \\
\text { Maine } \\
\text { N.H. } \\
\text { Vt. } \\
\text { Mass. } \\
\text { R.I. } \\
\text { Conn. }\end{array}$ & $\begin{array}{l}2 \\
1 \\
- \\
1 \\
- \\
- \\
-\end{array}$ & $\begin{array}{r}11 \\
- \\
1 \\
- \\
6 \\
- \\
4\end{array}$ & $\begin{array}{l}- \\
- \\
- \\
- \\
-\end{array}$ & $\begin{array}{l}- \\
- \\
- \\
- \\
-\end{array}$ & $\begin{array}{r}39 \\
2 \\
- \\
11 \\
26 \\
- \\
-\end{array}$ & $\begin{array}{r}57 \\
- \\
- \\
11 \\
46 \\
- \\
-\end{array}$ & $\begin{array}{r}18 \\
2 \\
- \\
3 \\
4 \\
2 \\
7\end{array}$ & $\begin{array}{r}21 \\
3 \\
- \\
6 \\
7 \\
3 \\
2\end{array}$ \\
\hline $\begin{array}{l}\text { MID. ATLANTIC } \\
\text { Upstate N.Y. } \\
\text { N.Y. City } \\
\text { N.J. } \\
\text { Pa. }\end{array}$ & $\begin{array}{l}9 \\
3 \\
1 \\
- \\
5\end{array}$ & $\begin{array}{r}25 \\
3 \\
5 \\
14 \\
3\end{array}$ & $\begin{array}{l}- \\
- \\
- \\
-\end{array}$ & $\begin{array}{l}- \\
- \\
- \\
-\end{array}$ & $\begin{array}{l}1 \\
1 \\
- \\
- \\
-\end{array}$ & $\begin{array}{l}5 \\
2 \\
3 \\
- \\
-\end{array}$ & $\begin{array}{r}27 \\
22 \\
- \\
- \\
5\end{array}$ & $\begin{array}{r}22 \\
13 \\
- \\
7 \\
2\end{array}$ \\
\hline $\begin{array}{l}\text { E.N. CENTRAL } \\
\text { Ohio } \\
\text { Ind. } \\
\text { III. } \\
\text { Mich. } \\
\text { Wis. }\end{array}$ & $\begin{array}{r}12 \\
11 \\
- \\
- \\
1 \\
-\end{array}$ & $\begin{array}{r}20 \\
5 \\
- \\
5 \\
6 \\
4\end{array}$ & $\begin{array}{l}- \\
- \\
- \\
- \\
-\end{array}$ & $\begin{array}{l}- \\
- \\
- \\
- \\
-\end{array}$ & $\begin{array}{r}21 \\
18 \\
- \\
- \\
3 \\
-\end{array}$ & $\begin{array}{r}29 \\
19 \\
- \\
- \\
2 \\
8\end{array}$ & $\begin{array}{l}1 \\
- \\
1 \\
- \\
- \\
-\end{array}$ & $\begin{array}{l}3 \\
- \\
- \\
- \\
1 \\
2\end{array}$ \\
\hline $\begin{array}{l}\text { W.N. CENTRAL } \\
\text { Minn. } \\
\text { lowa } \\
\text { Mo. } \\
\text { N. Dak. } \\
\text { S. Dak. } \\
\text { Nebr. } \\
\text { Kans. }\end{array}$ & $\begin{array}{l}2 \\
- \\
- \\
1 \\
- \\
1 \\
- \\
-\end{array}$ & $\begin{array}{l}5 \\
- \\
2 \\
3 \\
- \\
- \\
- \\
-\end{array}$ & $\begin{array}{l}- \\
- \\
- \\
- \\
- \\
-\end{array}$ & $\begin{array}{l}- \\
- \\
- \\
- \\
- \\
-\end{array}$ & $\begin{array}{r}11 \\
- \\
2 \\
9 \\
- \\
- \\
- \\
-\end{array}$ & $\begin{array}{r}12 \\
- \\
2 \\
6 \\
- \\
- \\
- \\
4\end{array}$ & $\begin{array}{l}2 \\
- \\
2 \\
- \\
- \\
- \\
- \\
-\end{array}$ & $\begin{array}{r}15 \\
4 \\
4 \\
1 \\
- \\
5 \\
- \\
1\end{array}$ \\
\hline $\begin{array}{l}\text { S. ATLANTIC } \\
\text { Del. } \\
\text { Md. } \\
\text { D.C. } \\
\text { Va. } \\
\text { W.Va. } \\
\text { N.C. } \\
\text { S.C. } \\
\text { Ga. } \\
\text { Fla. }\end{array}$ & $\begin{array}{l}6 \\
- \\
1 \\
- \\
- \\
- \\
1 \\
- \\
4 \\
-\end{array}$ & $\begin{array}{r}22 \\
- \\
4 \\
- \\
1 \\
- \\
6 \\
2 \\
6 \\
3\end{array}$ & $\begin{array}{l}- \\
- \\
- \\
- \\
- \\
- \\
- \\
-\end{array}$ & $\begin{array}{l}- \\
- \\
- \\
- \\
- \\
- \\
- \\
-\end{array}$ & $\begin{array}{l}5 \\
1 \\
2 \\
- \\
- \\
- \\
- \\
2 \\
- \\
-\end{array}$ & $\begin{array}{l}6 \\
- \\
3 \\
- \\
- \\
- \\
1 \\
2 \\
- \\
-\end{array}$ & $\begin{array}{r}39 \\
- \\
- \\
- \\
12 \\
3 \\
21 \\
3 \\
- \\
-\end{array}$ & $\begin{array}{r}53 \\
- \\
8 \\
- \\
6 \\
5 \\
12 \\
3 \\
15 \\
4\end{array}$ \\
\hline $\begin{array}{l}\text { E.S. CENTRAL } \\
\text { Ky. } \\
\text { Tenn. } \\
\text { Ala. } \\
\text { Miss. }\end{array}$ & $\begin{array}{l}1 \\
- \\
- \\
1 \\
-\end{array}$ & $\begin{array}{l}4 \\
- \\
1 \\
3 \\
-\end{array}$ & $\begin{array}{l}- \\
- \\
- \\
-\end{array}$ & $\begin{array}{l}- \\
- \\
- \\
-\end{array}$ & $\begin{array}{l}2 \\
1 \\
1 \\
- \\
-\end{array}$ & $\begin{array}{l}4 \\
- \\
2 \\
1 \\
1\end{array}$ & $\begin{array}{l}2 \\
- \\
1 \\
1 \\
-\end{array}$ & $\begin{array}{r}106 \\
- \\
106 \\
- \\
-\end{array}$ \\
\hline $\begin{array}{l}\text { W.S. CENTRAL } \\
\text { Ark. } \\
\text { La. } \\
\text { Okla. } \\
\text { Tex. }\end{array}$ & $\begin{array}{l}4 \\
2 \\
1 \\
- \\
1\end{array}$ & $\begin{array}{r}47 \\
- \\
5 \\
3 \\
39\end{array}$ & $\begin{array}{l}- \\
- \\
- \\
-\end{array}$ & $\begin{array}{l}- \\
- \\
- \\
-\end{array}$ & $\begin{array}{l}2 \\
2 \\
- \\
- \\
-\end{array}$ & $\begin{array}{l}- \\
- \\
-\end{array}$ & $\begin{array}{l}5 \\
- \\
- \\
5 \\
-\end{array}$ & $\begin{array}{r}45 \\
- \\
- \\
4 \\
41\end{array}$ \\
\hline $\begin{array}{l}\text { MOUNTAIN } \\
\text { Mont. } \\
\text { Idaho } \\
\text { Wyo. } \\
\text { Colo. } \\
\text { N. Mex. } \\
\text { Ariz. } \\
\text { Utah } \\
\text { Nev. }\end{array}$ & $\begin{array}{l}2 \\
- \\
- \\
- \\
2 \\
- \\
- \\
- \\
-\end{array}$ & $\begin{array}{l}9 \\
- \\
3 \\
- \\
3 \\
2 \\
- \\
1 \\
-\end{array}$ & $\begin{array}{l}- \\
- \\
- \\
- \\
- \\
- \\
-\end{array}$ & $\begin{array}{l}- \\
- \\
- \\
- \\
- \\
- \\
- \\
-\end{array}$ & $\begin{array}{r}20 \\
- \\
4 \\
- \\
10 \\
5 \\
- \\
1 \\
-\end{array}$ & $\begin{array}{r}34 \\
- \\
3 \\
- \\
30 \\
- \\
1 \\
- \\
-\end{array}$ & $\begin{array}{l}5 \\
- \\
- \\
- \\
- \\
- \\
5 \\
- \\
-\end{array}$ & $\begin{array}{r}15 \\
1 \\
- \\
5 \\
- \\
- \\
9 \\
- \\
-\end{array}$ \\
\hline $\begin{array}{l}\text { PACIFIC } \\
\text { Wash. } \\
\text { Oreg. } \\
\text { Calif. } \\
\text { Alaska } \\
\text { Hawaii }\end{array}$ & $\begin{array}{r}13 \\
1 \\
6 \\
6 \\
- \\
-\end{array}$ & $\begin{array}{r}21 \\
- \\
1 \\
16 \\
- \\
4\end{array}$ & $\begin{array}{r}2 \\
- \\
N \\
2 \\
- \\
-\end{array}$ & $\begin{array}{r}7 \\
- \\
N \\
5 \\
- \\
2\end{array}$ & $\begin{array}{l}5 \\
- \\
4 \\
- \\
1 \\
-\end{array}$ & $\begin{array}{r}24 \\
- \\
1 \\
19 \\
- \\
4\end{array}$ & $\begin{array}{l}2 \\
- \\
- \\
- \\
2 \\
-\end{array}$ & $\begin{array}{r}19 \\
- \\
- \\
9 \\
10 \\
-\end{array}$ \\
\hline $\begin{array}{l}\text { Guam } \\
\text { P.R. } \\
\text { V.I. } \\
\text { Amer. Samoa } \\
\text { C.N.M.I. }\end{array}$ & $\begin{array}{l}- \\
- \\
\\
-\end{array}$ & $\begin{array}{l}- \\
- \\
U\end{array}$ & $\begin{array}{l}- \\
- \\
\\
-\end{array}$ & $\begin{array}{l}- \\
- \\
U \\
U\end{array}$ & $\begin{array}{l}- \\
\\
\end{array}$ & $\begin{array}{c}- \\
\bar{U}\end{array}$ & $\begin{array}{l}- \\
- \\
\text { U }\end{array}$ & $\begin{array}{c}- \\
6 \\
- \\
U \\
U\end{array}$ \\
\hline
\end{tabular}

$\mathrm{N}$ : Not notifiable.

U: Unavailable.

- No reported cases.

* Incidence data for reporting year 2001 and 2002 are provisional and cumulative (year-to-date). 
TABLE II. (Cont'd) Provisional cases of selected notifiable diseases, United States, weeks ending January 19, 2002, and January 20, 2001 (3rd Week)*

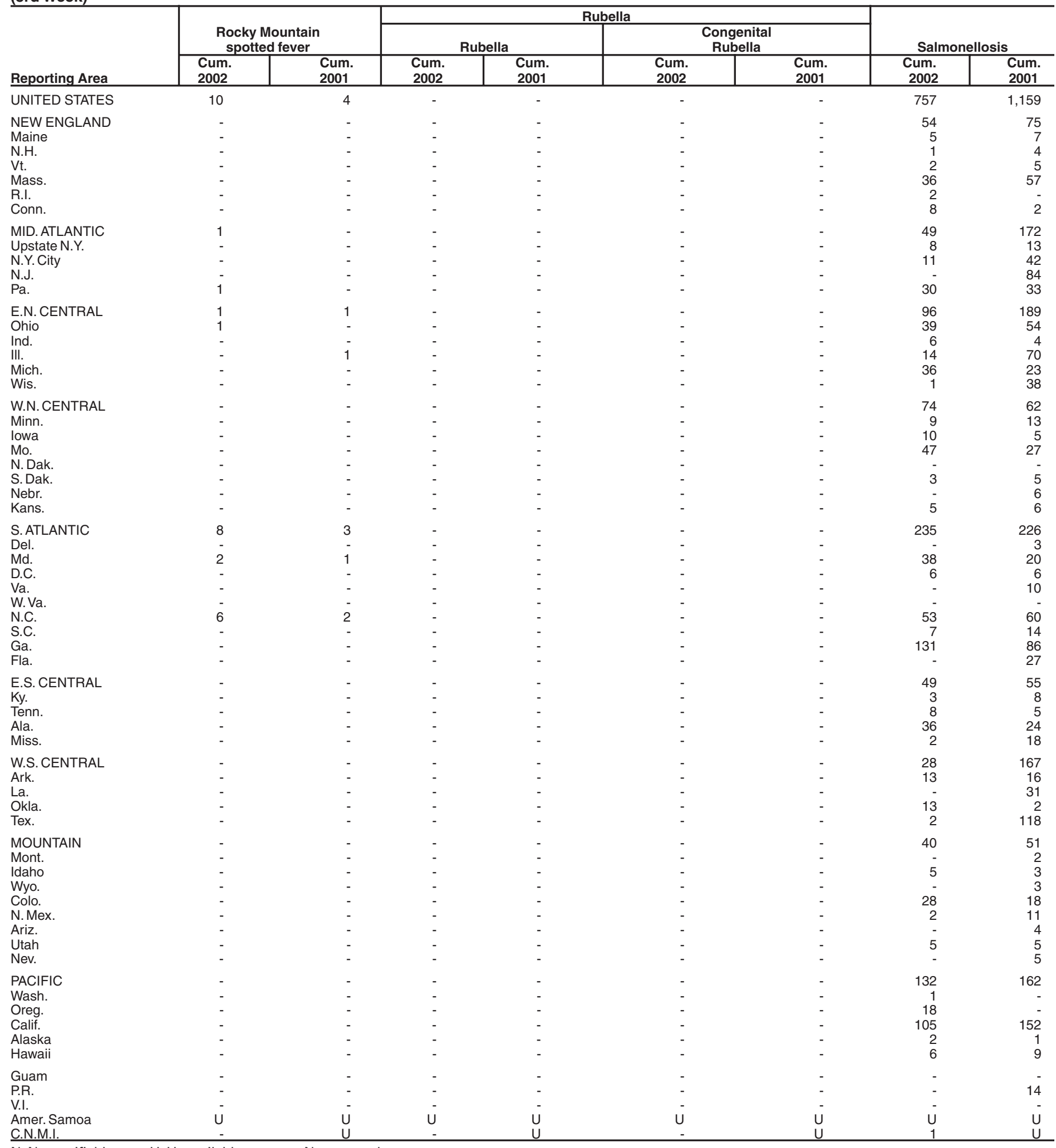

$\mathrm{N}$ : Not notifiable. $\quad \mathrm{U}$ : Unavailable.

$\therefore$ No reported cases.

* Incidence data for reporting year 2001 and 2002 are provisional and cumulative (year-to-date). 
TABLE II. (Cont'd) Provisional cases of selected notifiable diseases, United States, weeks ending January 19, 2002, and January 20, 2001 (3rd Week) $)^{*}$

\begin{tabular}{|c|c|c|c|c|c|c|c|c|}
\hline \multirow[b]{2}{*}{ Reporting Area } & \multicolumn{2}{|c|}{ Shigellosis } & \multicolumn{2}{|c|}{$\begin{array}{c}\text { Streptococcal Disease, } \\
\text { Invasive, Group A }\end{array}$} & \multicolumn{2}{|c|}{$\begin{array}{c}\text { Streptococcus pneumoniae, } \\
\text { Invasive ( }<5 \text { years) }\end{array}$} & \multicolumn{2}{|c|}{$\begin{array}{l}\text { Streptococcus pneumoniae } \\
\text { Drug Resistant, Invasive }\end{array}$} \\
\hline & $\begin{array}{l}\text { Cum. } \\
2002\end{array}$ & $\begin{array}{l}\text { Cum. } \\
2001\end{array}$ & $\begin{array}{l}\text { Cum. } \\
2002\end{array}$ & $\begin{array}{l}\text { Cum. } \\
2001\end{array}$ & $\begin{array}{l}\text { Cum. } \\
2002\end{array}$ & $\begin{array}{l}\text { Cum. } \\
2001\end{array}$ & \begin{tabular}{|l} 
Cum. \\
2002 \\
\end{tabular} & $\begin{array}{l}\text { Cum. } \\
2001\end{array}$ \\
\hline UNITED STATES & 324 & 664 & 124 & 205 & 18 & 3 & 61 & 80 \\
\hline $\begin{array}{l}\text { NEW ENGLAND } \\
\text { Maine } \\
\text { N.H. } \\
\text { Vt. } \\
\text { Mass. } \\
\text { R.I. } \\
\text { Conn. }\end{array}$ & $\begin{array}{l}8 \\
- \\
- \\
- \\
7 \\
- \\
1\end{array}$ & $\begin{array}{r}11 \\
- \\
- \\
10 \\
- \\
1\end{array}$ & $\begin{array}{l}4 \\
2 \\
1 \\
1 \\
- \\
- \\
-\end{array}$ & $\begin{array}{l}6 \\
2 \\
- \\
1 \\
3 \\
- \\
-\end{array}$ & $\begin{array}{l}5 \\
- \\
- \\
5 \\
- \\
- \\
-\end{array}$ & $\begin{array}{l}- \\
- \\
- \\
- \\
-\end{array}$ & $\begin{array}{l}- \\
- \\
- \\
- \\
- \\
- \\
-\end{array}$ & $\begin{array}{l}2 \\
- \\
- \\
2 \\
- \\
- \\
-\end{array}$ \\
\hline $\begin{array}{l}\text { MID. ATLANTIC } \\
\text { Upstate N.Y. } \\
\text { N.Y. City } \\
\text { N.J. } \\
\text { Pa. }\end{array}$ & $\begin{array}{r}10 \\
3 \\
1 \\
- \\
6\end{array}$ & $\begin{array}{r}102 \\
40 \\
29 \\
18 \\
15\end{array}$ & $\begin{array}{r}15 \\
10 \\
2 \\
- \\
3\end{array}$ & $\begin{array}{r}50 \\
6 \\
26 \\
18 \\
-\end{array}$ & $\begin{array}{l}- \\
- \\
- \\
-\end{array}$ & $\begin{array}{l}1 \\
1 \\
- \\
- \\
-\end{array}$ & $\begin{array}{l}2 \\
2 \\
- \\
- \\
-\end{array}$ & $\begin{array}{l}3 \\
3 \\
- \\
- \\
-\end{array}$ \\
\hline $\begin{array}{l}\text { E.N. CENTRAL } \\
\text { Ohio } \\
\text { Ind. } \\
\text { III. } \\
\text { Mich. } \\
\text { Wis. }\end{array}$ & $\begin{array}{r}84 \\
57 \\
3 \\
12 \\
12 \\
-\end{array}$ & $\begin{array}{r}97 \\
18 \\
4 \\
44 \\
24 \\
7\end{array}$ & $\begin{array}{r}26 \\
14 \\
- \\
1 \\
11 \\
-\end{array}$ & $\begin{array}{r}54 \\
5 \\
- \\
19 \\
28 \\
2\end{array}$ & $\begin{array}{r}12 \\
1 \\
11 \\
- \\
- \\
-\end{array}$ & $\begin{array}{l}2 \\
- \\
2 \\
- \\
- \\
-\end{array}$ & $\begin{array}{l}3 \\
1 \\
2 \\
- \\
- \\
-\end{array}$ & $\begin{array}{l}1 \\
- \\
1 \\
- \\
- \\
-\end{array}$ \\
\hline $\begin{array}{l}\text { W.N. CENTRAL } \\
\text { Minn. } \\
\text { lowa } \\
\text { Mo. } \\
\text { N. Dak. } \\
\text { S. Dak. } \\
\text { Nebr. } \\
\text { Kans. }\end{array}$ & $\begin{array}{r}71 \\
13 \\
5 \\
5 \\
- \\
45 \\
- \\
3\end{array}$ & $\begin{array}{r}95 \\
43 \\
6 \\
30 \\
- \\
1 \\
5 \\
10\end{array}$ & $\begin{array}{l}2 \\
- \\
- \\
1 \\
- \\
- \\
- \\
1\end{array}$ & $\begin{array}{r}12 \\
- \\
- \\
6 \\
- \\
2 \\
- \\
4\end{array}$ & $\begin{array}{l}- \\
- \\
- \\
- \\
- \\
- \\
- \\
-\end{array}$ & $\begin{array}{l}- \\
- \\
- \\
- \\
- \\
-\end{array}$ & $\begin{array}{l}6 \\
- \\
- \\
1 \\
- \\
- \\
- \\
5\end{array}$ & $\begin{array}{l}1 \\
- \\
- \\
- \\
- \\
- \\
- \\
1\end{array}$ \\
\hline $\begin{array}{l}\text { S. ATLANTIC } \\
\text { Del. } \\
\text { Md. } \\
\text { D.C. } \\
\text { Va. } \\
\text { W.Va. } \\
\text { N.C. } \\
\text { S.C. } \\
\text { Ga. } \\
\text { Fla. }\end{array}$ & $\begin{array}{r}60 \\
2 \\
18 \\
3 \\
- \\
- \\
14 \\
- \\
- \\
23 \\
-\end{array}$ & $\begin{array}{r}54 \\
- \\
3 \\
3 \\
3 \\
- \\
16 \\
6 \\
14 \\
9\end{array}$ & $\begin{array}{r}39 \\
- \\
5 \\
2 \\
- \\
- \\
6 \\
- \\
26 \\
-\end{array}$ & $\begin{array}{r}18 \\
- \\
4 \\
- \\
2 \\
- \\
6 \\
1 \\
3 \\
2\end{array}$ & $\begin{array}{l}1 \\
- \\
- \\
1 \\
- \\
- \\
- \\
- \\
- \\
-\end{array}$ & $\begin{array}{l}- \\
- \\
- \\
- \\
- \\
- \\
- \\
- \\
- \\
-\end{array}$ & $\begin{array}{r}45 \\
- \\
- \\
2 \\
- \\
- \\
- \\
9 \\
34 \\
-\end{array}$ & $\begin{array}{r}55 \\
- \\
- \\
- \\
- \\
- \\
- \\
7 \\
26 \\
22\end{array}$ \\
\hline $\begin{array}{l}\text { E.S. CENTRAL } \\
\text { Ky. } \\
\text { Tenn. } \\
\text { Ala. } \\
\text { Miss. }\end{array}$ & $\begin{array}{r}26 \\
3 \\
- \\
20 \\
3\end{array}$ & $\begin{array}{r}43 \\
18 \\
- \\
12 \\
13\end{array}$ & $\begin{array}{l}1 \\
- \\
1 \\
- \\
-\end{array}$ & $\begin{array}{l}3 \\
- \\
3 \\
- \\
-\end{array}$ & $\begin{array}{l}- \\
- \\
- \\
-\end{array}$ & $\begin{array}{l}- \\
- \\
- \\
-\end{array}$ & $\begin{array}{l}2 \\
- \\
2 \\
- \\
-\end{array}$ & $\begin{array}{l}3 \\
1 \\
2 \\
- \\
-\end{array}$ \\
\hline $\begin{array}{l}\text { W.S. CENTRAL } \\
\text { Ark. } \\
\text { La. } \\
\text { Okla. } \\
\text { Tex. }\end{array}$ & $\begin{array}{l}9 \\
6 \\
- \\
2 \\
1\end{array}$ & $\begin{array}{r}135 \\
7 \\
8 \\
- \\
120\end{array}$ & $\begin{array}{l}3 \\
- \\
- \\
2 \\
1\end{array}$ & $\begin{array}{r}25 \\
- \\
- \\
2 \\
23\end{array}$ & $\begin{array}{l}- \\
- \\
- \\
-\end{array}$ & $\begin{array}{l}- \\
- \\
- \\
-\end{array}$ & $\begin{array}{l}1 \\
1 \\
- \\
- \\
-\end{array}$ & $\begin{array}{r}13 \\
3 \\
10 \\
- \\
-\end{array}$ \\
\hline $\begin{array}{l}\text { MOUNTAIN } \\
\text { Mont. } \\
\text { Idaho } \\
\text { Wyo. } \\
\text { Colo. } \\
\text { N. Mex. } \\
\text { Ariz. } \\
\text { Utah } \\
\text { Nev. }\end{array}$ & $\begin{array}{r}13 \\
- \\
- \\
- \\
7 \\
1 \\
- \\
5 \\
-\end{array}$ & $\begin{array}{r}29 \\
- \\
1 \\
- \\
6 \\
11 \\
10 \\
- \\
1\end{array}$ & $\begin{array}{r}18 \\
- \\
- \\
- \\
11 \\
7 \\
- \\
- \\
-\end{array}$ & $\begin{array}{r}29 \\
- \\
- \\
- \\
19 \\
10 \\
- \\
- \\
-\end{array}$ & $\begin{array}{l}- \\
- \\
- \\
- \\
- \\
- \\
- \\
- \\
-\end{array}$ & $\begin{array}{l}- \\
- \\
- \\
- \\
- \\
- \\
-\end{array}$ & $\begin{array}{l}2 \\
- \\
- \\
- \\
- \\
2 \\
- \\
- \\
-\end{array}$ & $\begin{array}{l}2 \\
- \\
- \\
- \\
- \\
2 \\
- \\
- \\
-\end{array}$ \\
\hline $\begin{array}{l}\text { PACIFIC } \\
\text { Wash. } \\
\text { Oreg. } \\
\text { Calif. } \\
\text { Alaska } \\
\text { Hawaii }\end{array}$ & $\begin{array}{r}43 \\
- \\
8 \\
33 \\
- \\
2\end{array}$ & $\begin{array}{r}98 \\
- \\
- \\
98 \\
- \\
-\end{array}$ & $\begin{array}{r}16 \\
- \\
16 \\
-\end{array}$ & $\begin{array}{l}8 \\
- \\
- \\
8 \\
- \\
-\end{array}$ & $\begin{array}{l}- \\
- \\
- \\
- \\
-\end{array}$ & $\begin{array}{l}- \\
- \\
- \\
-\end{array}$ & $\begin{array}{l}- \\
- \\
- \\
- \\
- \\
-\end{array}$ & $\begin{array}{l}- \\
- \\
- \\
- \\
-\end{array}$ \\
\hline $\begin{array}{l}\text { Guam } \\
\text { P.R. } \\
\text { V.I. } \\
\text { Amer. Samoa } \\
\text { C.N.M.I. }\end{array}$ & $\begin{array}{l}- \\
- \\
\end{array}$ & $\begin{array}{l}- \\
1 \\
\\
U\end{array}$ & $\begin{array}{l}- \\
\\
\end{array}$ & $\begin{array}{l}- \\
- \\
\cup \\
U\end{array}$ & $\begin{array}{l}- \\
- \\
\text { U }\end{array}$ & $\begin{array}{l}- \\
\\
U\end{array}$ & $\begin{array}{l}- \\
- \\
- \\
-\end{array}$ & $\begin{array}{l}- \\
- \\
- \\
- \\
-\end{array}$ \\
\hline
\end{tabular}

$\mathrm{N}$ : Not notifiable. U: Unavailable.

- No reported cases.

* Incidence data for reporting year 2001 and 2002 are provisional and cumulative (year-to-date). 
TABLE II. (Cont'd) Provisional cases of selected notifiable diseases, United States, weeks ending January 19, 2002, and January 20, 2001 (3rd Week)*

\begin{tabular}{|c|c|c|c|c|c|c|c|c|}
\hline \multirow[b]{3}{*}{ Reporting Area } & \multicolumn{4}{|c|}{ Syphilis } & \multirow{2}{*}{\multicolumn{2}{|c|}{ Tuberculosis }} & \multirow{2}{*}{\multicolumn{2}{|c|}{$\begin{array}{c}\text { Typhoid } \\
\text { fever }\end{array}$}} \\
\hline & \multicolumn{2}{|c|}{ Primary \& Secondary } & \multicolumn{2}{|c|}{ Congenital $^{\dagger}$} & & & & \\
\hline & $\begin{array}{l}\text { Cum. } \\
2002\end{array}$ & $\begin{array}{l}\text { Cum. } \\
2001\end{array}$ & $\begin{array}{l}\text { Cum. } \\
2002\end{array}$ & $\begin{array}{l}\text { Cum. } \\
2001\end{array}$ & $\begin{array}{l}\text { Cum. } \\
2002\end{array}$ & $\begin{array}{l}\text { Cum. } \\
2001\end{array}$ & $\begin{array}{r}\text { Cum. } \\
2002\end{array}$ & $\begin{array}{l}\text { Cum. } \\
2001\end{array}$ \\
\hline UNITED STATES & 191 & 199 & - & 25 & 111 & 227 & 3 & 6 \\
\hline NEW ENGLAND & - & 2 & - & - & 8 & 2 & 2 & 1 \\
\hline Maine & - & - & - & - & - & - & - & - \\
\hline $\begin{array}{l}\text { N.H. } \\
V+\end{array}$ & - & - & - & - & - & j & - & - \\
\hline Mass. & - & - & - & - & - & - & 1 & 1 \\
\hline R.I. & - & - & - & - & 3 & - & - & - \\
\hline Conn. & - & 2 & - & - & 5 & 1 & 1 & - \\
\hline MID. ATLANTIC & 5 & 16 & - & 3 & 21 & 11 & - & - \\
\hline Upstate N.Y. & - & - & - & 1 & - & - & - & - \\
\hline N.Y. City & 4 & 8 & - & - & 7 & 4 & - & - \\
\hline N.J. & - & 2 & - & 2 & - & 5 & - & - \\
\hline $\mathrm{Pa}$. & 1 & 6 & - & - & 14 & 2 & - & - \\
\hline E.N. CENTRAL & 27 & 21 & - & 2 & 9 & 14 & - & 1 \\
\hline Ohio & 5 & 3 & - & - & 2 & 4 & - & - \\
\hline Ind. & 1 & 5 & - & - & $\overline{6}$ & 4 & - & - \\
\hline III. & 3 & 12 & - & 2 & 1 & 6 & - & 1 \\
\hline Mich. & 18 & - & - & - & - & - & - & - \\
\hline & - & 1 & - & - & - & - & - & - \\
\hline W.N. CENTRAL & - & 3 & - & 1 & 19 & 4 & - & 1 \\
\hline Minn. & - & 2 & - & - & 1 & 4 & - & - \\
\hline lowa & - & - & - & - & - & - & - & - \\
\hline & - & 1 & - & - & 18 & - & - & 1 \\
\hline N. Dak. & - & - & - & - & - & - & - & - \\
\hline S.Dak. & - & - & - & - & - & - & - & - \\
\hline Nebr. & - & - & - & - & - & - & - & - \\
\hline Kans. & - & - & - & 1 & - & - & - & - \\
\hline S. ATLANTIC & 52 & 78 & - & 8 & 3 & 21 & 1 & 1 \\
\hline Del. & - & & - & - & - & - & - & - \\
\hline & 5 & 10 & - & 1 & - & - & - & 1 \\
\hline D.C. & 3 & - & - & - & - & 3 & - & - \\
\hline & 3 & 6 & - & - & - & - & - & - \\
\hline W.Va. & - & - & - & - & 1 & 1 & - & - \\
\hline N.C. & 19 & 17 & - & - & 2 & - & - & - \\
\hline S.C. & 5 & 9 & - & 2 & - & 5 & - & - \\
\hline Ga. & 9 & 15 & - & 2 & - & 12 & 1 & - \\
\hline Fla. & 8 & 21 & - & 3 & - & - & - & - \\
\hline E.S. CENTRAL & 39 & 19 & - & - & 7 & 10 & - & - \\
\hline & 1 & 2 & - & - & - & - & - & - \\
\hline Tenn. & 16 & 8 & - & - & - & - & - & - \\
\hline Ala. & 20 & 4 & - & - & 7 & 10 & - & - \\
\hline Miss. & 2 & 5 & - & - & - & - & - & - \\
\hline W.S. CENTRAL & 40 & 35 & - & 4 & 1 & 82 & - & 1 \\
\hline Ark. & & 5 & - & 2 & - & 8 & - & - \\
\hline La. & 14 & 8 & - & - & - & - & - & - \\
\hline Okla. & 7 & 3 & - & - & 1 & - & - & - \\
\hline Tex. & 19 & 19 & - & 2 & - & 74 & - & 1 \\
\hline MOUNTAIN & 18 & 3 & - & 1 & 2 & 8 & - & - \\
\hline Mont. & - & - & - & - & - & - & - & - \\
\hline Idaho & 1 & - & - & - & - & - & - & - \\
\hline Wyo. & - & - & - & - & - & - & - & - \\
\hline Colo. & - & - & - & - & - & 1 & - & - \\
\hline N. Mex. & 3 & - & - & - & - & 2 & - & - \\
\hline Ariz. & 14 & 2 & - & 1 & 2 & 2 & - & - \\
\hline Utah & - & 1 & - & - & - & - & - & - \\
\hline Nev. & - & - & - & - & - & 3 & - & - \\
\hline PACIFIC & 10 & 22 & - & 6 & 41 & 75 & - & 1 \\
\hline Wash. & 1 & 3 & - & - & 4 & 9 & - & - \\
\hline Oreg. & - & 2 & - & - & & 3 & - & - \\
\hline Calif. & 9 & 16 & - & 6 & 30 & 52 & - & 1 \\
\hline Alaska & - & - & - & - & 1 & 3 & - & - \\
\hline Hawaii & - & 1 & - & - & 6 & 8 & - & - \\
\hline Guam & - & - & - & - & - & - & - & - \\
\hline & - & 21 & - & - & - & - & - & - \\
\hline V.I. & - & - & - & - & - & - & - & - \\
\hline Amer. Samoa & U & U & U & $U$ & U & U & U & U \\
\hline C.N.M.I. & 1 & U & - & U & 2 & U & - & U \\
\hline
\end{tabular}

N: Not notifiable. $\quad$ U: Unavailable. $\quad-:$ No reported cases.

* Incidence data for reporting year 2001 and 2002 are provisional and cumulative (year-to-date).

+ Updated from reports to the Division of STD Prevention, NCHSTP. 
TABLE III. Deaths in 122 U.S. cities, ${ }^{*}$ week ending January 19, 2002 (3rd Week)

\begin{tabular}{|c|c|c|c|c|c|c|c|c|c|c|c|c|c|c|c|}
\hline \multirow[b]{2}{*}{ Reporting Area } & \multicolumn{6}{|c|}{ All Causes, By Age (Years) } & \multirow[b]{2}{*}{$\begin{array}{l}\text { P\& }\left.\right|^{\dagger} \\
\text { Total }\end{array}$} & \multirow[b]{2}{*}{ Reporting Area } & \multicolumn{6}{|c|}{ All Causes, By Age (Years) } & \multirow[b]{2}{*}{$\begin{array}{l}\text { P\&l } \\
\text { Total } \\
\end{array}$} \\
\hline & $\begin{array}{c}\text { All } \\
\text { Ages }\end{array}$ & $\geq 65$ & 45-64 & $25-44$ & $1-24$ & $<1$ & & & \begin{tabular}{|c|} 
All \\
Ages
\end{tabular} & $\geq 65$ & $45-64$ & $25-44$ & $1-24$ & $<1$ & \\
\hline NEW ENGLAND & 611 & 455 & 94 & 30 & 9 & 23 & 77 & S. ATLANTIC & 1,293 & 833 & 280 & 102 & 31 & 46 & 98 \\
\hline Boston, Mass. & 193 & 138 & 32 & 5 & 4 & 14 & 29 & Atlanta, Ga. & 211 & 138 & 45 & 12 & 7 & 9 & 6 \\
\hline Bridgeport, Conn. & 29 & 21 & 5 & 3 & - & - & 1 & Baltimore, Md. & 192 & 97 & 60 & 28 & 3 & 4 & 26 \\
\hline Cambridge, Mass. & 18 & 15 & 3 & - & - & - & 4 & Charlotte, N.C. & 128 & 97 & 23 & 6 & - & 2 & 15 \\
\hline Fall River, Mass. & 32 & 29 & 2 & - & 1 & - & 1 & Jacksonville, Fla. & 164 & 111 & 34 & 9 & 3 & 6 & 18 \\
\hline Hartford, Conn. & 48 & 34 & 6 & 5 & 2 & 1 & 6 & Miami, Fla. & 23 & 13 & 6 & 2 & - & 2 & 2 \\
\hline Lowell, Mass. & 19 & 15 & 3 & 1 & - & - & 8 & Norfolk, Va. & 74 & 45 & 14 & 6 & 4 & 5 & 5 \\
\hline Lynn, Mass. & 3 & 2 & 1 & - & - & - & 1 & Richmond, Va. & 101 & 57 & 25 & 14 & 2 & 3 & 9 \\
\hline New Bedford, Mass. & 24 & 21 & 1 & 2 & - & - & 4 & Savannah, Ga. & 45 & 34 & 11 & - & - & - & 3 \\
\hline New Haven, Conn. & 43 & 34 & 8 & 1 & - & - & 6 & St. Petersburg, Fla. & 71 & 55 & 7 & 5 & 1 & 3 & 3 \\
\hline Providence, R.I. & 68 & 46 & 12 & 4 & 1 & 5 & 1 & Tampa, Fla. & 184 & 125 & 35 & 10 & 6 & 8 & 9 \\
\hline Somerville, Mass. & 5 & 4 & - & 1 & - & - & 1 & Washington, D.C. & 100 & 61 & 20 & 10 & 5 & 4 & 2 \\
\hline Springfield, Mass. & 47 & 30 & 10 & 4 & 1 & 2 & 5 & Wilmington, Del. & U & U & $U$ & U & U & u & U \\
\hline Waterbury, Conn. & 14 & 8 & 4 & 1 & - & 1 & - & E.S. CENTRAL & 1.088 & 757 & 208 & 75 & 28 & 19 & 97 \\
\hline Worcester, Mass. & 68 & 58 & 7 & 3 & - & - & 10 & Birmingham, Ala. & 258 & 188 & 41 & 13 & 10 & 5 & 27 \\
\hline MID. ATLANTIC & 2,501 & 1,741 & 524 & 158 & 30 & 44 & 144 & Chattanooga, Tenn. & 73 & 54 & 14 & 4 & 1 & - & 9 \\
\hline Albany, N.Y. & 54 & 38 & 13 & 3 & - & - & - & Knoxville, Tenn. & 135 & 92 & 29 & 10 & 3 & 1 & 3 \\
\hline Allentown, $\mathrm{Pa}$. & 15 & 13 & 2 & - & - & - & 1 & Lexington, Ky. & 98 & 62 & 20 & 12 & 1 & 3 & 8 \\
\hline Buffalo, N.Y. & 62 & 54 & 7 & 1 & - & - & 4 & Memphis, Tenn. & 201 & 138 & 41 & 14 & 6 & 2 & 22 \\
\hline Camden, N.J. & 24 & 16 & 6 & 1 & - & 1 & 3 & Mobile, Ala. & 109 & 72 & 19 & 11 & 1 & 6 & 5 \\
\hline Elizabeth, N.J. & 33 & 21 & 11 & 1 & - & - & - & Montgomery, Ala. & 48 & 34 & 11 & 2 & 1 & - & 5 \\
\hline Erie, $\mathrm{Pa}$ & 59 & 45 & 8 & 3 & 1 & 2 & 3 & Nashville, Tenn. & 166 & 117 & 33 & 9 & 5 & 2 & 18 \\
\hline Jersey City, N.J. & 59 & 41 & 11 & 5 & 2 & - & - & WS CENTRAL & 983 & 660 & 213 & 68 & 16 & 26 & 64 \\
\hline New York City, N.Y. & 1,372 & 921 & 304 & 98 & 15 & 31 & 72 & $\begin{array}{l}\text { W.S. CENI RAL } \\
\text { Austin, Tex. }\end{array}$ & $\begin{array}{l}983 \\
124\end{array}$ & $\begin{array}{r}660 \\
81\end{array}$ & $\begin{array}{r}213 \\
31\end{array}$ & $\begin{array}{r}68 \\
9\end{array}$ & $\begin{array}{r}16 \\
1\end{array}$ & $\begin{array}{r}26 \\
2\end{array}$ & $\begin{array}{r}64 \\
9\end{array}$ \\
\hline Newark, N.J. & U & U & U & U & U & U & U & Baton Rouge, La. & 80 & 49 & 21 & 8 & 2 & - & 1 \\
\hline Paterson, N.J. & 25 & 12 & 6 & 5 & 2 & - & 3 & Corpus Christi, Tex. & 74 & 54 & 16 & 3 & 1 & - & 4 \\
\hline Philadelphia, Pa. & 321 & 199 & 85 & 26 & 6 & 4 & 14 & Dallas, Tex. & u & u & U & u & u & u & u \\
\hline Pittsburgh, $\mathrm{Pa} .^{\S}$ & 36 & 26 & 9 & - & 1 & - & 3 & El Paso, Tex. & U & $\mathrm{U}$ & $\mathrm{U}$ & U & u & u & u \\
\hline Reading, $\mathrm{Pa}$. & 30 & 23 & 3 & 4 & - & - & 4 & Ft. Worth, Tex. & 160 & 88 & 50 & 14 & 4 & 4 & 6 \\
\hline Rochester, N.Y. & 129 & 104 & 21 & 2 & - & 2 & 13 & Houston, Tex. & $\mathrm{U}$ & U & u & U & U & U & U \\
\hline Schenectady, N.Y. & 23 & 20 & 2 & 1 & - & - & 2 & Little Rock, Ark. & 70 & 41 & 17 & 4 & 2 & 6 & 2 \\
\hline Scranton, Pa. & 26 & 22 & 3 & 1 & - & - & - & New Orleans, La. & $\mathrm{U}$ & $\mathrm{U}$ & u & U & U & u & U \\
\hline Syracuse, N.Y. & 164 & 133 & 25 & 4 & 1 & 1 & & San Antonio, Tex. & 257 & 191 & 40 & 17 & 2 & 7 & 23 \\
\hline Trenton, N.J. & 44 & 31 & 8 & 1 & 1 & 3 & 1 & Shreveport, La. & 65 & 46 & 10 & 5 & 2 & 2 & 5 \\
\hline $\begin{array}{l}\text { Utica, N.Y. } \\
\text { Yonkers, N.Y. }\end{array}$ & $\begin{array}{r}25 \\
u\end{array}$ & 22 & - & 2 & 1 & - & 1 & Tulsa, Okla. & 153 & 110 & 28 & 8 & 2 & 5 & 14 \\
\hline Yonkers, N.Y. & & & U & U & U & U & & MOUNTAIN & 949 & 649 & 187 & 64 & 21 & 24 & 87 \\
\hline $\begin{array}{l}\text { E.N. CENTRAL } \\
\text { Akron, Ohio }\end{array}$ & $\begin{array}{r}1,922 \\
60\end{array}$ & $\begin{array}{r}1,350 \\
42\end{array}$ & $\begin{array}{r}380 \\
11\end{array}$ & $\begin{array}{r}113 \\
3\end{array}$ & $\begin{array}{r}33 \\
1\end{array}$ & $\begin{array}{r}46 \\
3\end{array}$ & $\begin{array}{r}159 \\
7\end{array}$ & Albuquerque, N.M. & 151 & 108 & 28 & 12 & 2 & 1 & 14 \\
\hline & $\begin{array}{l}60 \\
40\end{array}$ & $\begin{array}{l}42 \\
27\end{array}$ & $\begin{array}{r}11 \\
9\end{array}$ & $\begin{array}{l}3 \\
2\end{array}$ & 1 & ${ }^{3}$ & $\frac{7}{5}$ & Boise, Idaho & 54 & 40 & 12 & 1 & - & 1 & 3 \\
\hline Chicago, III. & U & U & $\mathrm{U}$ & U & u & u & u & Colo. Springs, Colo. & 67 & 48 & 13 & 4 & - & 2 & 5 \\
\hline Cincinnati, Ohio & 103 & 76 & 13 & 10 & 2 & 2 & 15 & Denver, Colo. & 102 & 56 & 26 & 11 & 3 & 6 & 13 \\
\hline Cleveland, Ohio & 147 & 81 & 46 & 12 & 5 & 3 & 8 & Las Vegas, Nev. & 243 & 165 & 46 & 19 & 4 & 8 & 16 \\
\hline Columbus, Ohio & 237 & 155 & $\begin{array}{l}40 \\
49\end{array}$ & 25 & - & 8 & 11 & Ogden, Utah & 32 & 22 & 5 & 4 & - & 1 & 3 \\
\hline Dayton, Ohio & 174 & 130 & 24 & 15 & 3 & 2 & 24 & Phoenix, Ariz. & 151 & 102 & 33 & 7 & 6 & - & 13 \\
\hline Detroit, Mich. & 214 & 122 & $\begin{array}{l}24 \\
62\end{array}$ & 13 & 8 & 9 & $\begin{array}{l}24 \\
19\end{array}$ & Pueblo, Colo. & 39 & 32 & 4 & - & 3 & - & 4 \\
\hline Evansville, Ind. & 47 & 39 & 6 & 1 & - & 1 & & Salt Lake City, Utah & 110 & 76 & 20 & 6 & 3 & 5 & 16 \\
\hline Fort Wayne, Ind. & $\begin{array}{l}4 ! \\
89\end{array}$ & 71 & $\begin{array}{r}0 \\
11\end{array}$ & 5 & 1 & 1 & $\begin{array}{l}1 \\
6\end{array}$ & Tucson, Ariz. & U & u & U & u & U & $u$ & U \\
\hline Gary, Ind. & 18 & 7 & 9 & 2 & - & - & 1 & PACIFIC & 2,034 & 1,437 & 383 & 132 & 52 & 27 & 161 \\
\hline Grand Rapids, Mich. & 82 & 68 & 10 & 1 & 2 & 1 & 6 & Berkeley, Calif. & 19 & 11 & 8 & - & - & - & - \\
\hline Indianapolis, Ind. & 214 & 151 & 49 & 7 & 4 & 3 & 18 & Fresno, Calif. & 171 & 129 & 27 & 11 & 4 & - & 13 \\
\hline Lansing, Mich. & 49 & 41 & 6 & 2 & - & - & 7 & Glendale, Calif. & 22 & 19 & & 3 & - & - & 4 \\
\hline Milwaukee, Wis. & 135 & 99 & 25 & 5 & 2 & 4 & 4 & Honolulu, Hawaii & 109 & 84 & 15 & 8 & 1 & 1 & 11 \\
\hline Peoria, III. & 52 & 36 & 8 & 4 & 1 & 3 & 4 & Long Beach, Calif. & 100 & 70 & 17 & 10 & - & 3 & 13 \\
\hline Rockford, III. & 47 & 32 & 10 & 2 & 2 & 1 & 6 & Los Angeles, Calif. & 382 & 246 & 77 & 32 & 19 & 8 & 21 \\
\hline South Bend, Ind. & 46 & 36 & 9 & - & 1 & - & 7 & Pasadena, Calif. & 40 & 33 & 6 & 1 & - & - & 8 \\
\hline Toledo, Ohio & 97 & 76 & 17 & 1 & - & 3 & 7 & Portland, Oreg. & 260 & 193 & 51 & 9 & 5 & 2 & 24 \\
\hline Youngstown, Ohio & 71 & 61 & 6 & 3 & 1 & - & 3 & Sacramento, Calif. & 229 & 155 & 53 & 10 & 8 & 3 & 7 \\
\hline W.N. CENTRAL & & 517 & 145 & 49 & 22 & 13 & 53 & San Diego, Calif. & 176 & 112 & 43 & 12 & 6 & 3 & 13 \\
\hline Des Moines, lowa & $\begin{array}{r}140 \\
99\end{array}$ & 68 & 25 & $\begin{array}{r}45 \\
5\end{array}$ & 1 & - & 10 & San Francisco, Calif. & U & U & U & U & U & U & $\mathrm{U}$ \\
\hline $\begin{array}{l}\text { Duluth, Minn. } \\
\text { Din }\end{array}$ & 9 & 8 & 1 & - & - & - & 10 & San Jose, Calif. & 237 & 166 & 49 & 13 & 5 & 1 & 24 \\
\hline Kansas City, Kans. & 30 & 16 & 8 & 5 & 1 & - & 3 & Santa Cruz, Calif. & 31 & 25 & 5 & 1 & - & - & 5 \\
\hline Kansas City, Mo. & 113 & 67 & 28 & 9 & 7 & 2 & 4 & Seattle, Wash. & 154 & 109 & 20 & 17 & 3 & 5 & 12 \\
\hline Lincoln, Nebr. & 39 & 30 & 6 & - & 2 & 1 & 3 & Spokane, Wash. & U & U & $u$ & $u$ & U & u & $U$ \\
\hline Minneapolis, Minn. & 99 & 75 & 15 & 6 & 2 & 1 & 9 & Tacoma, Wash. & 104 & 85 & 12 & 5 & 1 & 1 & 6 \\
\hline Omaha, Nebr. & 117 & 82 & 23 & 6 & 5 & 1 & 11 & TOTAL & $12,127^{\pi}$ & 8,399 & 2,414 & 791 & 242 & 268 & 940 \\
\hline St. Louis, Mo. & 53 & 39 & 7 & 4 & 2 & 1 & - & & & & & & & & \\
\hline St. Paul, Minn. & 74 & 58 & 11 & 2 & - & 3 & 5 & & & & & & & & \\
\hline Wichita, Kans. & 113 & 74 & 21 & 12 & 2 & 4 & 8 & & & & & & & & \\
\hline
\end{tabular}

U: Unavailable. - :No reported cases.

* Mortality data in this table are voluntarily reported from 122 cities in the United States, most of which have populations of $\geq 100,000$. A death is reported by the place of its occurrence and by the week that the death certificate was filed. Fetal deaths are not included.

+ Pneumonia and influenza.

${ }^{\S}$ Because of changes in reporting methods in this Pennsylvania city, these numbers are partial counts for the current week. Complete counts will be available in 4 to 6 weeks.

"Total includes unknown ages. 
All $M M W R$ references are available on the Internet at http://www.cdc.gov/mmwr. Use the search function to find specific articles.

Use of trade names and commercial sources is for identification only and does not imply endorsement by the U.S. Department of Health and Human Services.

References to non-CDC sites on the Internet are provided as a service to $M M W R$ readers and do not constitute or imply endorsement of these organizations or their programs by CDC or the U.S. Department of Health and Human Services. CDC is not responsible for the content of pages found at these sites. 
The Morbidity and Mortality Weekly Report (MMWR) Series is prepared by the Centers for Disease Control and Prevention (CDC) and is available free of charge in electronic format and on a paid subscription basis for paper copy. To receive an electronic copy on Friday of each week, send an e-mail message to listserv@listserv.cdc.gov. The body content should read SUBscribe mmwr-toc. Electronic copy also is available from CDC's World-Wide Web server at $h t t p: / / w w w . c d c . g o v / m m w r$ or from CDC's file transfer protocol server at ftp://ftp.cdc.gov/ pub/Publications/mmwr. To subscribe for paper copy, contact Superintendent of Documents, U.S. Government Printing Office, Washington, DC 20402; telephone (202) 512-1800.

Data in the weekly MMWR are provisional, based on weekly reports to CDC by state health departments. The reporting week concludes at close of business on Friday; compiled data on a national basis are officially released to the public on the following Friday. Address inquiries about the MMWR Series, including material to be considered for publication, to: Editor, MMWR Series, Mailstop C-08, CDC, 1600 Clifton Rd., N.E., Atlanta, GA 30333; telephone (888) 232-3228.

All material in the MMWR Series is in the public domain and may be used and reprinted without permission; citation as to source, however, is appreciated.

¿̌t U.S. Government Printing Office: 2002-733-100/69006 Region IV 